\title{
Upregulation of KCC2 Activity by Zinc-Mediated Neurotransmission via the mZnR/GPR39 Receptor
}

\author{
Ehud Chorin, ${ }^{1 \star}$ Ofir Vinograd, ${ }^{1 \star}$ Ilya Fleidervish, ${ }^{2}$ David Gilad, ${ }^{1}$ Sharon Herrmann, ${ }^{2}$ Israel Sekler, ${ }^{2}$ Elias Aizenman,, 3 \\ and Michal Hershfinkel ${ }^{1}$ \\ Departments of ${ }^{1}$ Morphology and ${ }^{2}$ Physiology, Faculty of Health Sciences and The Zlotowski Center of Neuroscience, Ben-Gurion University, Beer-Sheva, \\ 84015, Israel, and ${ }^{3}$ Department of Neurobiology, University of Pittsburgh School of Medicine, Pittsburgh, Pennsylvania 15261
}

Vesicular $\mathrm{Zn}^{2+}$ regulates postsynaptic neuronal excitability upon its corelease with glutamate. We previously demonstrated that synaptic $\mathrm{Zn}^{2+}$ acts via a distinct metabotropic zinc-sensing receptor $(\mathrm{mZnR})$ in neurons to trigger $\mathrm{Ca}^{2+}$ responses in the hippocampus. Here, we show that physiological activation of $\mathrm{mZnR}$ signaling induces enhanced $\mathrm{K}^{+} / \mathrm{Cl}^{-}$cotransporter 2 (KCC2) activity and surface expression. As KCC2 is the major $\mathrm{Cl}^{-}$outward transporter in neurons, $\mathrm{Zn}^{2+}$ also triggers a pronounced hyperpolarizing shift in the $\mathrm{GABA}_{\mathrm{A}}$ reversal potential. Mossy fiber stimulation-dependent upregulation of KCC2 activity is eliminated in slices from $\mathrm{Zn}^{2+}$ transporter 3-deficient animals, which lack synaptic $\mathrm{Zn}^{2+}$. Importantly, activity-dependent $\mathrm{ZnR}$ signaling and subsequent enhancement of KCC2 activity are also absent in slices from mice lacking the G-protein-coupled receptor GPR39, identifying this protein as the functional neuronal $\mathrm{mZnR}$. Our work elucidates a fundamentally important role for synaptically released $\mathrm{Zn}^{2+}$ acting as a neurotransmitter signal via activation of a mZnR to increase $\mathrm{Cl}^{-}$transport, thereby enhancing inhibitory tone in postsynaptic cells.

\section{Introduction}

Neurons contain two major pools of $\mathrm{Zn}^{2+}$. One pool is composed of $\mathrm{Zn}^{2+}$ bound to intracellular proteins, such as enzymes, transcription factors and metal-binding proteins. This bound $\mathrm{Zn}^{2+}$ can be liberated into the cytoplasm during oxidative or nitrosative neuronal injury, leading to cell death (Aizenman et al., 2000; Zhang et al., 2004, 2006; Redman et al., 2009). The second pool is synaptic $\mathrm{Zn}^{2+}$, packaged into a subpopulation of glutamate-containing synaptic vesicles by the $\mathrm{Zn}^{2+}$ transporter 3 (ZnT3), and released into the synaptic cleft during neuronal activity in a $\mathrm{Ca}^{2+}$-dependent manner (Qian and Noebels, 2005, 2006; Paoletti et al., 2009). Vesicular $\mathrm{Zn}^{2+}$ regulates neuronal excitability and can strongly influence seizure activity (Vogt et al., 2000; Smart et al., 2004; Sensi et al., 2009). Indeed, removal of synaptic $\mathrm{Zn}^{2+}$ by dietary means, chemical chelation, or via genetic deletion of ZnT3, leads to enhanced susceptibility to epileptic seizures (Cole et al., 2000; Blasco-Ibáñez et al., 2004; Takeda et al., 2005), a phenomenon that may be reflective of some forms of human epilepsy (Goldberg and Sheehy, 1982; Ganesh and Jana-

\footnotetext{
Received May 3, 2011; revised July 12, 2011; accepted July 14, 2011.

Author contributions: E.C., I.S., E.A., and M.H. designed research; E.C., O.V., I.F., D.G., S.H., and M.H. performed research; E.C., O.V., I.F., and M.H. analyzed data; I.S., E.A., and M.H. wrote the paper.

This work was supported by the US-Israel Binational Science Foundation (Grant BSF2007121 to M.H. and E.A.), by the Israel Science Foundation (Grant 585/05 to M.H.), and by the US National Institutes of Health (Grant NSO43277 to E.A.). We thank R. Palmiter from the University of Washington for the ZnT3 KO mice and advice. The GPR39 KO mice were kindly provided by D. Moechars from Johnson \& Johnson Pharmaceutical Research and Development, a Division of Janssen Pharmaceutica. The $G \alpha q$ inhibitor YM-254890 was a kind gift from Astellas Pharma Inc. We thank Drs. K. Kandler, P. Rosenberg, and E. Levitan for helpful discussions and suggestions.

*E.C. and O.V. contributed equally to this study.

Correspondence should be addressed to Dr. Michal Hershfinkel, Department of Morphology and the Zlotowski Center of Neuroscience, Ben-Gurion University, POB 653, Beer-Sheva, 84105, Israel. E-mail: hmichal@bgu.ac.il.

DOI:10.1523/JNEUROSCI.2205-11.2011

Copyright $\odot 2011$ the authors $\quad 0270-6474 / 11 / 3112916-11 \$ 15.00 / 0$
}

kiraman, 2008). By comparison, elevation of $\mathrm{Zn}^{2+}$ levels either by dietary means or by direct infusion into the brain can delay seizures in kindled animals (Fukahori and Itoh, 1990; Elsas et al., 2009).

Synaptic $\mathrm{Zn}^{2+}$ is known to allosterically modulate glutamate, GABA and glycine ionotropic receptors (Smart et al., 2004; Madry et al., 2008; Paoletti et al., 2009), and has heretofore been classified as a neuromodulator (Laube et al., 1995; Vogt et al., 2000; Hosie et al., 2003; Smart et al., 2004; Paoletti et al., 2009). However, the recent identification of a metabotropic $\mathrm{Zn}^{2+}$ sensing receptor $(\mathrm{mZnR})$ in hippocampal neurons suggests that synaptically released $\mathrm{Zn}^{2+}$ can profoundly alter postsynaptic cell function via a distinct Gq-linked pathway that triggers the release of $\mathrm{Ca}^{2+}$ from intracellular stores (Besser et al., 2009). GPR39, a previously considered orphan Gq-coupled receptor, was shown to mediate $\mathrm{Zn}^{2+}$-dependent signaling in a recombinant expression system (Yasuda et al., 2007), and we have recently suggested that this receptor is linked to $\mathrm{mZnR}$ activity in the CA3 region of the hippocampus based on its expression pattern (Besser et al., 2009). Here, using pharmacological and genetic tools, we firmly establish GPR39 as the molecular determinant behind neuronal $\mathrm{mZnR}$ function. Importantly, we report that the physiological activation of $\mathrm{mZnR} / \mathrm{GPR} 39$ in CA3 neurons leads to an increase in surface expression and activity of the $\mathrm{K}^{+} / \mathrm{Cl}^{-}$cotransporter 2 (KCC2), the principal $\mathrm{Cl}^{-}$outward transporter critical for the maintenance of hyperpolarizing $\mathrm{GABA}_{\mathrm{A}}$ reversal potentials (Rivera et al., 1999; Woo et al., 2002).

\section{Materials and Methods}

Slice preparation and stimulation. Experimental procedures were performed in accordance with a protocol approved by the committee for the Ethical Care and Use of Animal in Experiments at the Faculty of Health Sciences at Ben-Gurion University. Hippocampal slices were obtained 
A

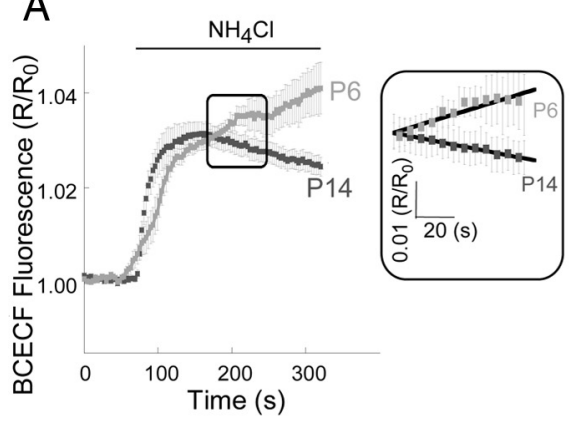

B

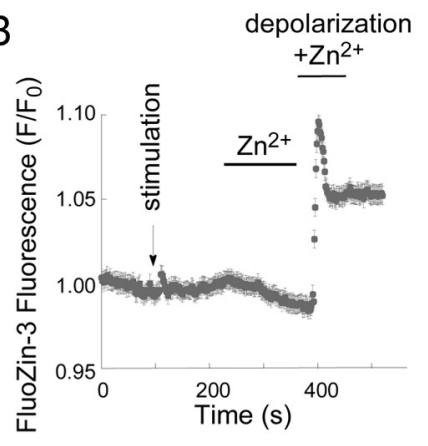

C

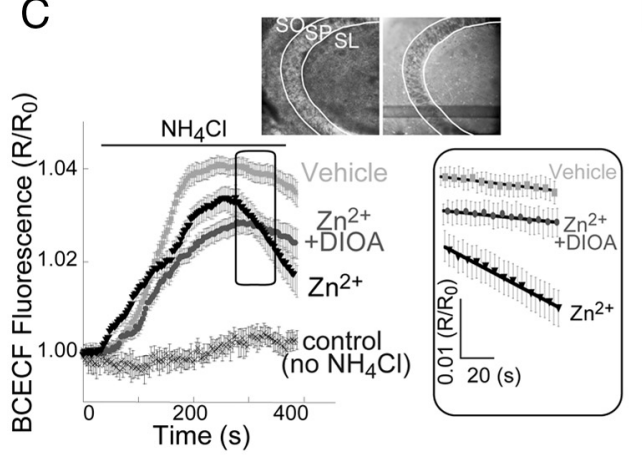

$\mathrm{D}$

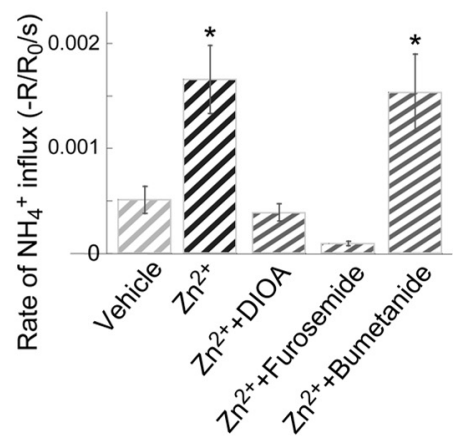

$\mathrm{E}$
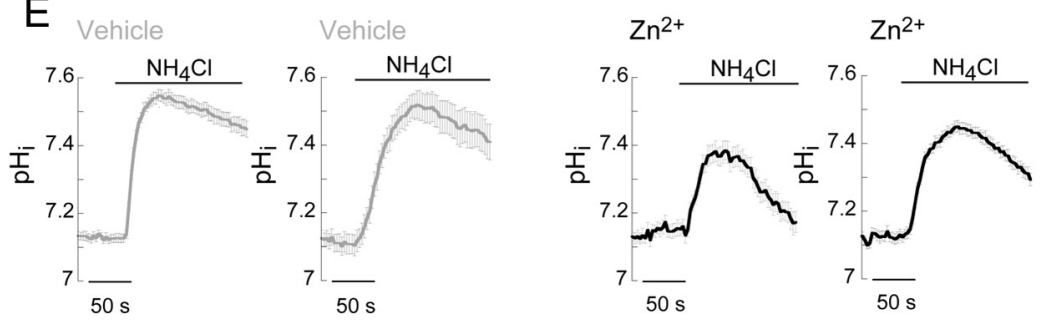

Figure 1. Extracellular $\mathrm{Zn}^{2+}$ upregulates $\mathrm{NH}_{4}{ }^{+}$-dependent influx mediated by $\mathrm{KCC} 2$ activity. $\boldsymbol{A}$, To assess $\mathrm{KCC} 2$ transport activity, we monitored BCECF fluorescence in acute mouse hippocampal slices using the $\mathrm{NH}_{4}{ }^{+}$transport paradigm. Application of $\mathrm{NH}_{4} \mathrm{Cl}(5 \mathrm{~mm})$ induces initial alkalinization (due to passive diffusion of $\mathrm{NH}_{3}$ through the cell membrane). Subsequent $\mathrm{NH}_{4}{ }^{+}$influx via $\mathrm{KCC}$, acting in reverse mode, induces acidification of the cells, and the initial rate of acidification represents $\mathrm{KCC} 2$ activity (see Materials and Methods). This paradigm was applied to slices obtained from 6- or 14-d-old mice ( $n=4$ slices). Inset shows the signal in the region marked by the box, where the linear regression curve was fitted to represent $\mathrm{KCC} 2$ activity. Note that for clarity of the inset only every second measurement is shown. Averaged rates of $\mathrm{NH}_{4}{ }^{+}$influx were $0.0006 \pm 0.0004\left(R / R_{0} / s\right)$ in P6 slices and $-0.0004 \pm 0.0003\left(R / R_{0} / s\right)$ in P14 slices $\left({ }^{*} p<0.05\right) . B$, Intracellular $Z n^{2+}$ concentration in slices loaded with FluoZin-3, following (at indicated times) electrical stimulation (Besser et al., 2009), addition of $\mathrm{Zn}^{2+}(200 \mu \mathrm{m})$ and depolarization using ACSF containing $50 \mathrm{~mm} \mathrm{KCl}$ (replacing $\mathrm{NaCl})$ in the presence of $\mathrm{Zn}^{2+}(200 \mu \mathrm{m})$. Only following depolarization, in the presence of $\mathrm{Zn}^{2+}$, a rise in fluorescence was observed ( $n=3$ slices). C, Averaged traces from BCECF-loaded slices ( $n=8$ slices), imaged with or without application of $\mathrm{NH}_{4} \mathrm{Cl}(5 \mathrm{~mm})$ in the presence or absence of DIOA (100 $\left.\mu \mathrm{M}\right)$. Slices were pretreated with extracellular $\mathrm{Zn}^{2+}$ (200 $\mu \mathrm{M}, 2 \mathrm{~min}$ ) or maintained in ACSF (vehicle) and imaged within $2 \mathrm{~min}$. In the box, the signal from the region marked in the graph is depicted, and the linear regression curve that was fitted to represent $\mathrm{KCC} 2$ activity is shown. Note that for clarity only every second measurement is shown. Inset shows bright-field (left) and BCECF fluorescence (right) images of the CA3 region that was monitored; $\mathrm{SO}$ stratum oriens, $\mathrm{SL}$ stratum lucidum. $\boldsymbol{D}$, Averaged rate of acidification due to steady-state $\mathrm{NH}_{4}{ }^{+}$influx $\pm \mathrm{SEM}(n=$ 8 slices, ${ }^{*} p<0.05$ compared with vehicle control). The rate of $\mathrm{NH}_{4}{ }^{+}$influx is enhanced following pretreatment with extracellular $\mathrm{Zn}^{2+}$, and is blocked by DIOA $(100 \mu \mathrm{M})$ or furosemide $(100 \mu \mathrm{M})$ but not by the $\mathrm{Na}^{+} / \mathrm{K}^{+} / \mathrm{Cl}^{-}$cotransporter inhibitor bumetanide $(1 \mu \mathrm{M})$. $\boldsymbol{E}$, Shown are representative traces from slices exposed to $\mathrm{NH}_{4} \mathrm{Cl}$ that were calibrated to $\mathrm{pH}_{i}$, using the calibration curve (see Materials and Methods). Each trace is an average of 7-12 ROIs within the somatic CA3 region from a single slice. Slices were treated with $\mathrm{Zn}^{2+}$ (200 $\mu \mathrm{m}, 2 \mathrm{~min}$ ) or maintained in ACSF (vehicle) as marked.

from postnatal day 12 (P12)-P15 mice of either sex, following protocols aimed to preserve mossy fiber structure (Amaral and Witter, 1989; Bischofberger et al., 2006; Amaral et al., 2007). In one series of control experiments we used slices obtained from P6 mice (Fig. 1A). Transverse slices $(400 \mu \mathrm{m})$ were kept in artificial CSF (ACSF) at room temperature. To test the effect of extracellular $\mathrm{Zn}^{2+}$, slices were transferred to $\mathrm{NaH}_{2} \mathrm{PO}_{4}$-free ACSF to prevent precipitation of the metal (Besser et al., 2009). Slices were then either pretreated with physiologically relevant concentrations of $\mathrm{Zn}^{2+}(200 \mu \mathrm{M})$ for $2 \mathrm{~min}$ (Vogt et al., 2000; Qian and Noebels, 2005), or mossy fibers were subjected to electrical stimulation (a train of 10 pulses at $66 \mathrm{~Hz}$; Master-8 stimulator unit, A.M.P.I.) (Qian and Noebels, 2005; Frederickson et al., 2006; Besser et al., 2009). Both stimuli were previously shown to induce similar ZnR-dependent $\mathrm{Ca}^{2+}$ responses in the postsynaptic cells in CA3 (Besser et al., 2009). Following exogenous $\mathrm{Zn}^{2+}$ treatment, the solution was replaced with $\mathrm{Zn}^{2+}$. free ACSF solution, and slices were quickly placed in the recording chamber. Imaging of KCC2 activity always started within 2 min following the end of the $\mathrm{Zn}^{2+}$-treatment. The mossy fiber stimulated slices were kept in the recording chamber and perfused with $\mathrm{Zn}^{2+}$ free ACSF solution for $\sim 2 \mathrm{~min}$. Since KCC2 may undergo rapid recycling, this timing was carefully maintained for all paradigms used. Inhibitors of the Gq-coupled receptor, PLC and MEK1/2 (YM-254890, U73122, U0126), a signaling pathway activated by the $\mathrm{ZnR}$, were applied 30 min before application of $\mathrm{Zn}^{2+}$.

Fluorescence imaging. Slices were loaded with either Fura-2 AM $(25 \mu \mathrm{M}$, TefLabs) or BCECF AM [2',7'-bis-(2-carboxyethyl)-5-(and-6)-carboxyfluorescein AM] $(25 \mu \mathrm{M}$, TefLabs $)$ for 20 min or with MQAE [ $N$-(ethoxycarbonylmethyl)-6-methoxy-quinolinium bromide] (5 $\mathrm{mm}$, TefLabs) or FluoZin-3 AM ( $25 \mu \mathrm{M}$, Invitrogen) for $30 \mathrm{~min}$, all AM dyes were applied in the presence of $0.02 \%$ pluronic acid. Slices were then washed for at least $20 \mathrm{~min}$ in ACSF (Beierlein et al., 2002; Besser et al., 2009). Fluorescent imaging measurements, focusing on CA3, were acquired every $3 \mathrm{~s}$ (Imaging Workbench 4, INDEC BioSystems; and polychrome monochromator, TILL Photonics) using a $10 \times$ objective (Olympus BX51) with $4 \times 4$ binning of the image (SensiCam, PCO). Under these conditions, minimal bleaching was observed and the fluorescence signal from a large number of CA3 neurons could be acquired (Besser et al., 2009). In each slice 9-15 traces from individual regions of interest (ROIs) were acquired in the pyramidal cell layer [stratum pyramidale (SP)], established by a bright-field image acquired before each measurement. All ROIs were randomly selected within the somatic SP region as observed in the bright-field image (Fig. 1C). All selected ROIs in a slice were included in subsequent analyses.

Synaptic $\mathrm{Zn}^{2+}$ release in the CA3 was detected using the extracellular $\mathrm{Zn}^{2+}$-sensitive fluorescent dye Newport Green DCF $(2 \mu \mathrm{M}$; Invitrogen) (Frederickson et al., 2006), F being the intensity of the fluorescent signal obtained using $480 \mathrm{~nm}$ excitation and a $535 \mathrm{~nm}$ bandpass emission filter (Chroma Technology). Intracellular $\mathrm{Zn}^{2+}$ measurements were performed using FluoZin-3-loaded slices; $F$ is the intensity of the fluorescent signal obtained using the same filters used for Newport Green. Intracellular $\mathrm{Ca}^{2+}$ signals were monitored in slices loaded with Fura-2. The loading procedure used in these experiments is similar to that used previously by our group, shown to effectively label neuronal cells within the CA3 region (Besser et al., 2009). Fluorescence signals are represented as a ratio, $R$, of the signal obtained using excitation of $340 \mathrm{~nm} / 380 \mathrm{~nm}$ wavelengths and a $510 \mathrm{~nm}$ emission bandpass filter (Chroma Technology). Baseline fluorescent sig- 
nals were obtained by averaging over the initial $10 \mathrm{~s}$ period $\left(F_{0}\right.$ for Newport Green and $R_{0}$ for Fura-2) and subsequent fluorescence levels were normalized to this value (Hershfinkel et al., 2001), thus minimizing variations related to dye loading (Reynolds, 2001). Averaged traces of ROIs from at least three independent experiments are presented as $R / R_{0}$ or $F / F_{0} \pm$ SEM, the number of slices averaged is marked $n$ in the figure legend.

For measurements of KCC2 activity two independent paradigms were used. In each of these paradigms slices were loaded with a specific fluorescent indicator, then treated with extracellular $\mathrm{Zn}^{2+}$, or maintained in ACSF in control experiments, and imaged, within 2 min wash in ACSF, to determine rates of KCC2 activity. In one paradigm, slices were loaded with the $\mathrm{H}^{+}$indicator BCECF. $R$ is the ratio of the emitted signal obtained using excitation wavelength of $440 \mathrm{~nm} / 480 \mathrm{~nm}$ and a bandpass emission filter at $535 \mathrm{~nm}$ (Chroma Technology) and $R_{0}$ is the initial baseline as described above. Slices were perfused with ACSF to obtain a baseline and then $\mathrm{NH}_{4} \mathrm{Cl}(5 \mathrm{~mm})$ was added, replacing $\mathrm{KCl}$ in the ACSF. Alkalinization of the cells following passive entry of $\mathrm{NH}_{3}$ into the cells was initially observed, as reported earlier (Titz et al., 2006); the time required to reach a steady concentration of $\mathrm{NH}_{3}$ within the cells varied, likely due to different permeation times within the slice. Extracellular $\mathrm{NH}_{4}{ }^{+}$serves as a surrogate to $\mathrm{K}^{+}$and reversal of $\mathrm{KCC} 2$ activity induces its transport into the cells leading to a pronounced decrease of cellular $\mathrm{pH}$ following the alkalinization phase (Titz et al., 2006). This acidification in the presence of $\mathrm{NH}_{4} \mathrm{Cl}$, results from $\mathrm{NH}_{4}{ }^{+}$influx at steady state and represents KCC2 activity. Rates of steady-state $\mathrm{NH}_{4}{ }^{+}$influx were determined by monitoring the initial $75 \mathrm{~s}$ period of the decrease in intracellular pH (Shin et al., 2004; Hershfinkel et al., 2009), thus minimizing the exposure to $\mathrm{NH}_{4} \mathrm{Cl}$ (Bonnet and Wiemann, 1999) and the potential effects of $\mathrm{pH}$ regulatory mechanisms. BCECF fluorescence was calibrated using $10 \mu \mathrm{M}$ nigericin in oxygenated $\left(100 \% \mathrm{O}_{2}\right)$ solution containing the following (in mM): $118 \mathrm{KCl}, 3 \mathrm{NaCl}, 1 \mathrm{MgCl}_{2}, 1.5 \mathrm{CaCl}_{2}, 25 \mathrm{HEPES}$, and 10 glucose (Ritucci et al., 1996; Trapp et al., 1996; Ruusuvuori et al., 2004). Values of $\mathrm{pH}_{\mathrm{i}}$ were plotted as a function of the fluorescence signal and fitted to produce a calibration curve, which was used to calculate $\mathrm{pH}_{\mathrm{i}}$ in some slices exposed to the $\mathrm{NH}_{4} \mathrm{Cl}$ paradigm (Fig. $1 F$ ). In a second paradigm, slices were loaded with the $\mathrm{Cl}^{-}$indicator MQAE. With this technique, $F$ is the intensity of the fluorescent signal obtained at $360 \mathrm{~nm}$ excitation and $510 \mathrm{~nm}$ emission bandpass filter (Chroma Technology) and $F_{0}$ is the initial baseline as describe above. Following baseline acquisition, ACSF containing a final concentration of $10 \mathrm{~mm} \mathrm{KCl}$ was applied, leading to reverse, $\mathrm{Cl}^{-}$influx through KCC2 and quenching of MQAE fluorescence (Galeffi et al., 2004; Pond et al., 2004). Care was taken to apply $\mathrm{KCl}$ after thorough washout of $\mathrm{Zn}^{2+}$, thereby minimizing permeation of this metal ion via voltage-activated ion channels (Sensi et al., 2000). A $30 \mathrm{~s}$ period of perfusion with the $\mathrm{KCl}$ solution was allowed for $\mathrm{KCl}$ equilibration within the slice, and rates of $\mathrm{Cl}^{-}$influx during the subsequent $50 \mathrm{~s}$ period were determined. Calibration of MQAE fluorescence using the $\mathrm{K}^{+} / \mathrm{H}^{+}$ionophore nigericin $(10 \mu \mathrm{M})$ and the $\mathrm{Cl}^{-} / \mathrm{OH}^{-}$ antiporter tributyltin chloride $(10 \mu \mathrm{M})$ yielded a Stern-Volmer constant (Verkman, 1990) of $23 \pm 1 \mathrm{M}^{-1}$ ( or $K_{\mathrm{d}}$ of $\sim 44 \mathrm{mM} \mathrm{Cl}^{-}$), in agreement with previous works (Marandi et al., 2002). Inhibitors of KCC2 or NKCC1 [dihydroindenyl-oxy-alkanoic acid (DIOA), bumetanide, furosemide] were added as indicated to the perfusing ACSF solutions. Representative traces from single slices as well as averaged traces of all ROIs are presented as $R / R_{0}$ or $F / F_{0} \pm$ SEM (BCECF or MQAE, respectively), the number of slices averaged is marked $n$ in the figure legend. Averaged initial rates of fluorescence change (fitted as described above) due to KCC2 activity \pm SEM are presented in bar graphs. Statistical significance was determined using $t$ test or ANOVA with post hoc Tukey comparisons where appropriate.

Surface expression and immunoblotting. Changes in KCC2 membrane expression were monitored as previously described (Rivera et al., 2002; Thomas-Crusells et al., 2003) using hippocampal slices. Acute slices were biotinylated (100 $\mu \mathrm{M}$ sulfo-NHS-Biotin, Pierce) in ACSF (45 min, at room temperature) and then unbound sulfo-NHS-biotin was scavenged using $1 \mu \mathrm{M}$ lysine in ACSF ( 2 times). Some slices were also loaded with Fura- 2 and the $\mathrm{ZnR}$-dependent $\mathrm{Ca}^{2+}$ responses were monitored (see Fig. $5 C$ ). For surface expression analysis, biotinylated slices were incubated with $\mathrm{Zn}^{2+}(200 \mu \mathrm{M}, 2 \mathrm{~min})$ at room temperature in the presence or absence of the G $\alpha \mathrm{q}$ inhibitor YM-254890. Slices maintained in $\mathrm{Zn}^{2+}$. free ACSF for the same time interval were used as control, detecting the basal, time-dependent removal of biotinylated KCC2 from the surface membrane (Rivera et al., 2004; Lee et al., 2007; Zhao et al., 2008). Slices were washed in ACSF and $\sim 6$ min following $\mathrm{Zn}^{2+}$ or control treatment, slices were lysed (1\% Triton X-100, 0.1\% SDS, 1 mm EDTA, $50 \mathrm{~mm}, \mathrm{NaCl}$, $20 \mathrm{~mm}$ Tris-HCl, pH 7.5, and protease inhibitors, Sigma) and Neutravidin Gel (Pierce) was added (overnight at $4^{\circ} \mathrm{C}$ ), as previously described (Rivera et al., 2004). Samples were resolved on 7.5\% SDS-PAGE followed by immunoblot analysis of KCC2 (C2366, Sigma) and transferrin receptor (13-6800, Invitrogen), a nonrelated surface protein which was used for normalization. Immunoblots were digitally imaged using ChemImager5 (Alpha-Innotech, Labtrade), and quantified using EZQuant-Gel software.

Electrophysiological recordings. Whole-cell or cell-attached recordings from CA3 neurons were either made blindly (Hamill et al., 1981; Blanton et al., 1989) or under infrared-differential interference contrast microscopic control (Stuart et al., 1993). For blind recording, the slices were maintained in a small ( $300 \mu \mathrm{l}$ ) interface-type recording chamber (Haas et al., 1979); for visually controlled recording, slices were held submerged in a chamber on the fixed stage of an Axioskop FS microscope (Carl Zeiss). All recordings were made at $32 \pm 1^{\circ} \mathrm{C}$. Patch pipettes were manufactured from thick-walled borosilicate glass capillaries (1.5 mm o.d., Hilgenberg, Germany) and had resistances of 1.5-3.5 M $\Omega$. For cell-attached recordings, pipettes containing $5 \mu \mathrm{M}$ GABA in ACSF were coated to within $\sim 100 \mu \mathrm{m}$ of the tip with Sylgard (Dow Corning). The pipette solution for whole-cell current-clamp experiments contained the following (in $\mathrm{mM}$ ): $130 \mathrm{~K}$-gluconate, $6 \mathrm{KCl}, 2 \mathrm{MgCl}_{2}, 10 \mathrm{HEPES}$ (potassium salt), $\mathrm{pH}$ 7.25. Leak subtraction and channel openings detection was made using pCLAMP 9.0 software (Molecular Devices).

Single $\mathrm{GABA}_{\mathrm{A}}$ channel openings were obtained in cell-attached patches using an Axopatch 200B amplifier (Molecular Devices), and whole-cell current-clamp voltage recordings from the soma were obtained using an Axoclamp-2B amplifier in bridge mode. Command voltage protocols were generated and single-channel data were acquired on-line with a Digidata 1320A A/D interface. Data were low-pass filtered at $2-5 \mathrm{kHz}(-3 \mathrm{~dB}, 4$-pole Bessel filter $)$ and digitized at $10-20 \mathrm{kHz}$. Capacitive and leak currents were reduced before data acquisition using the built-in circuits of the amplifier. For whole-cell current-clamp recordings, data were low-pass filtered at $10 \mathrm{kHz}(-3 \mathrm{~dB}$, single-pole Bessel filter) and digitized at $50 \mathrm{kHz}$. Data were fitted using Origin 6.0 (OriginLab, Northampton, MA). Values are given as mean \pm SD. For statistical analysis, a paired Student's $t$ test was performed.

Genotyping of mice. PCR was used to screen GPR39 genotypes from mouse biopsy samples (Moechars et al., 2006). Primers 5'-ACCCTCAT CTTGGTGTACCT- ${ }^{\prime}$ and $5^{\prime}$-ATGTAGCG CTCAAAGCTGAG- ${ }^{\prime}$ amplified a $311 \mathrm{bp}$ band from the wild-type allele, whereas primers $5^{\prime}$-GG AAvCTCTCACTCGACCTGGG-3' and 5'-GCAGCGCAT CGCCTTCT ATC-3' amplified a 262 bp band from the knock-out allele.

Cell culture and GPR39 silencing. Human neuroblastoma SH-SY5Y cells were cultured in DMEM as previously described (Kan et al., 2007). For gene silencing experiments, cells were cotransfected with silencing constructs, $3 \mu \mathrm{g}$ of siGPR39 or siT1R3 using LipofectAMINE 2000 as directed by the manufacturer (Invitrogen), and imaged $48 \mathrm{~h}$ following transfection. The target sequence of the human GPR39 for siRNA was CCATGGAGTTCTACAGCATtt and that of human T1R3 was CUUAGGAUGAAGGGGGACUtt. ZnR activity, using Fura-2 (Besser et al., 2009), or KCC2 activity, using the BCECF and MQAE paradigms, were measured in Ringer's solution, using the same procedures described above.

\section{Results}

\section{Extracellular $\mathrm{Zn}^{2+}$ upregulates KCC2 activity}

We explored whether mZnR affected the activity of KCC2, a transporter strongly regulated by alterations in $\left[\mathrm{Ca}^{2+}\right]_{\mathrm{i}}($ Fiumelli et al., 2005). To monitor KCC2 activity we measured influx rates of $\mathrm{NH}_{4}{ }^{+}$, a surrogate ion for $\mathrm{K}^{+}$, using the $\mathrm{pH}$-sensitive dye 

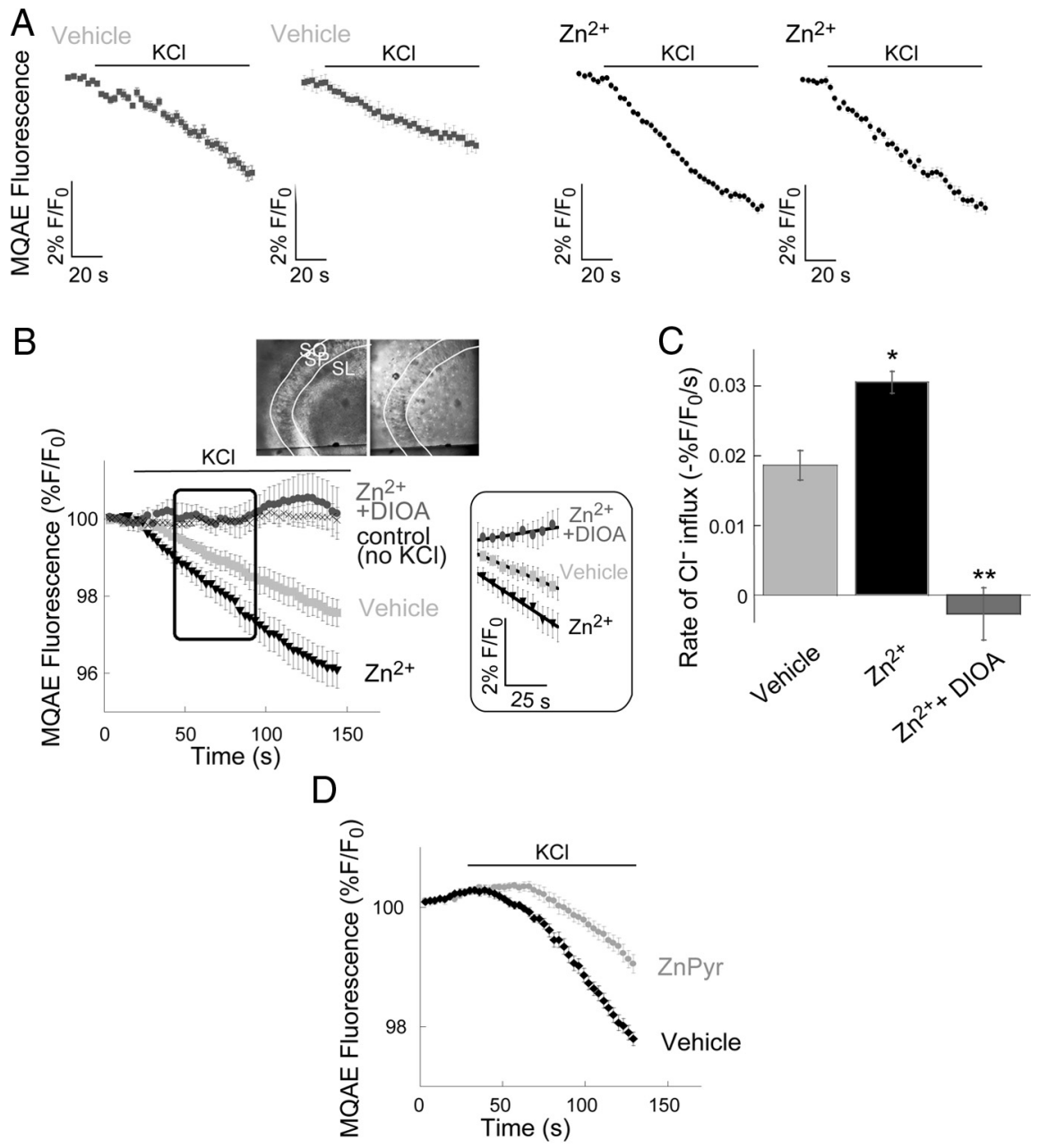

Figure 2. Extracellular $\mathrm{Zn}^{2+}$ upregulates $\mathrm{Cl}^{-}$-dependent influx mediated by $\mathrm{KCC} 2$ activity. $A$, Representative traces from slices loaded with the $\mathrm{Cl}^{-}$-sensitive dye MQAE (Hershfinkel et al., 2009), each trace is an average of 7-12 ROls within the somatic CA3 region of one slice. Slices were treated with $\mathrm{Zn}^{2+}$ (200 $\mu \mathrm{m}, 2 \mathrm{~min}$ ) or maintained in ACSF (vehicle). Within $2 \mathrm{~min}$ of the $\mathrm{Zn}^{2+}$ treatment slices were imaged and $10 \mathrm{~mm} \mathrm{KCl}$ was added as indicated. $\boldsymbol{B}$, Averaged traces from slices treated with or without $10 \mathrm{~mm}$ $\mathrm{KCl}$. Shown are traces from control slices (vehicle, $n=7$ slices), slices pretreated with extracellular $\mathrm{Zn}^{2+}(200 \mu \mathrm{m}, 2 \mathrm{~min}, n=7$ slices), slices treated with $\mathrm{Zn}^{2+}$ in the presence of the KCC2 inhibitor DIOA (100 $\mu \mathrm{M}, n=10$ slices) or control slices, without $\mathrm{KCl}$ ( $n=9$ slices). Inset shows the CA3 region that was imaged (left, bright-field; right, fluorescent images); SO stratum oriens, SL stratum lucidum. In the box, the signal from the region marked in the graph is depicted, and the linear regression curve that was fitted to represent KCC2 activity is shown. Note that for clarity every second measurement is shown. C, Averaged rates \pm SEM $(n=$ 7 slices for vehicle or $\mathrm{Zn}^{2+}$-treated, and 10 slices for $\left.\mathrm{Zn}^{2+}+\mathrm{DIOA}\right)$ of $\mathrm{Cl}^{-}$influx as monitored in $\boldsymbol{B}\left({ }^{*} p<0.05,{ }^{* *} p<0.01\right.$ compared with vehicle control). $\boldsymbol{D}$, The effect of intracellular $\mathrm{Zn}^{2+}$ rise on $\mathrm{KCC} 2$ activity was determined in MQAE-loaded slices, as in $\boldsymbol{A}$. Shown are averaged traces from control slices (vehicle) or slices pretreated with $\mathrm{Zn}^{2+}(100 \mu \mathrm{M})$ in the presence of its ionophore pyrithione $(5 \mu \mathrm{M})$, marked as $\mathrm{ZnPyr}\left(n=5\right.$ slices). Averaged rates of $\mathrm{Cl}^{-}$influx were $0.033 \pm 0.004\left(-\% \mathrm{~F} / \mathrm{F}_{0} / \mathrm{s}\right)$ in vehicle control slices and $0.017 \pm 0.002\left(-\% F / F_{0} / s\right)$ in the ZnPyR-treated slices $\left({ }^{*} p<0.05\right)$.

BCECF (Hershfinkel et al., 2009). In agreement with the previously described developmental expression of KCC2 (Rivera et al., 1999), $\mathrm{NH}_{4}{ }^{+}$transport, measured as the rate of BCECF fluorescence quenching, was observed in slices from $\mathrm{P} 14$ mice, but not in slices from postnatal day 6 mice (Fig. $1 A$ ). To study the effect of $\mathrm{mZnR}$, slices were treated with $200 \mu \mathrm{M} \mathrm{Zn}{ }^{2+}$ for $2 \mathrm{~min}$, a paradigm that activates mZnR signaling (Besser et al., 2009) without increasing $\left[\mathrm{Zn}^{2+}\right]_{\mathrm{i}}$ (Fig. $1 \mathrm{~B}$ ). We then measured $\mathrm{NH}_{4}{ }^{+}$transport rate, mediated by KCC2, in P12-P15 slices following ZnR activation or in controls that were maintained in nominally $\mathrm{Zn}^{2+}$ free ACSF (vehicle). We observed that extracellular $\mathrm{Zn}^{2+}$ treatment induced a pronounced increase the rate of $\mathrm{NH}_{4}{ }^{+}$transport in CA3 neurons compared with vehicle control (Fig. 1C). Importantly, $\mathrm{NH}_{4}{ }^{+}$transport following $\mathrm{Zn}^{2+}$ application was inhibited by the
KCC2 inhibitors DIOA (100 $\mu \mathrm{M})$ and furosemide $(100 \mu \mathrm{M})$, but not by the $\mathrm{Na}^{+} / \mathrm{K}^{+} /$ $\mathrm{Cl}^{-}$cotransporter inhibitor bumetanide (1 $\mu \mathrm{M}$; Fig. $1 D$ ) suggesting that this transport is predominantly mediated by KCC2 activity. In a small subset of slices, we calibrated the decrease in BCECF fluorescence to changes intracellular $\mathrm{pH}$ using nigericin (Fig. $1 E$ ), as previously described (Trapp et al., 1996; Ruusuvuori et al., 2004). Following calibration, the rate of $\mathrm{pH}$ change in the $\mathrm{Zn}^{2+}$. treated slices was $0.002 \pm 0.0003 \mathrm{pH}_{\mathrm{i}} / \mathrm{s}$, while in control slices rates were only $0.0006 \pm 0.0002 \mathrm{pH}_{\mathrm{i}} / \mathrm{s} \quad(n=3$ for each group). Thus, in these experiments, the effects of $\mathrm{Zn}^{2+}$ on KCC2 were essentially identical to those described above.

We next studied the effect of $\mathrm{mZnR}$ activation on KCC2 by directly monitoring the rate of $\left[\mathrm{Cl}^{-}\right]$transport (Hershfinkel et al., 2009), using the fluorescent dye MQAE following application of $10 \mathrm{~mm}$ $\mathrm{KCl}$, which reverses KCC2 transport and results in $\mathrm{Cl}^{-}$influx. Similar to what we observed using the BCECF-based method, extracellular $\mathrm{Zn}^{2+}$ application $(200 \mu \mathrm{M}, 2$ min) significantly enhanced the $\mathrm{Cl}^{-}$influx rates in CA3 neurons compared with the influx rate monitored in controls (Fig. $2 A-C)$. The KCC2 inhibitor DIOA (100 $\mu \mathrm{M})$ completely blocked $\mathrm{Cl}^{-}$influx in the $\mathrm{Zn}^{2+}$-treated slices, suggesting that both the basal and $\mathrm{Zn}^{2+}$-enhanced $\mathrm{Cl}^{-}$transport was mediated by KCC2 (Fig. $2 B, C$ ). These results, combined with those described earlier, strongly suggest that extracellular $\mathrm{Zn}^{2+}$, under conditions associated with $\mathrm{ZnR}$ activation (Hershfinkel et al., 2001; Besser et al., 2009), can produce pronounced enhancement of KCC2 activity. It is noteworthy that in a recent study we demonstrated that a rise in intracellular $\mathrm{Zn}^{2+}$ can strongly attenuate KCC2-mediated activity, both in a recombinant expression system and in dissociated cortical neurons (Hershfinkel et al., 2009). We therefore confirmed that this phenomenon could also be discerned in brain slices. To raise intracellular $\mathrm{Zn}^{2+}$ in hippocampal slices (P12-P15), before imaging KCC2 activity, we applied $\mathrm{Zn}^{2+}(100 \mu \mathrm{M})$ together with the $\mathrm{Zn}^{2+}$ ionophore pyrithione ( $\mathrm{ZnPyr} ; 5 \mu \mathrm{M})$. Slices were washed in $\mathrm{Zn}^{2+}$-free ACSF and then imaged for KCC2 activity using the MQAE paradigm as in Figure 2, $A$ and $B$. In contrast to the actions of extracellular $\mathrm{Zn}^{2+}$, and in agreement with our prior work (Hershfinkel et al., 2009), the ZnPyr treatment induced a significant attenuation of the rate of $\mathrm{Cl}^{-}$transport in CA3 neurons (Fig. 2D).

Extracellular $\mathrm{Zn}^{2+}$ induces alterations in $E_{\mathrm{GABA}}$ By modulating the $\mathrm{Cl}^{-}$gradient, KCC2 strongly influences the reversal potential of $\mathrm{GABA}_{\mathrm{A}}$ receptor-mediated ionic currents $\left(E_{\mathrm{GABA}}\right)$ (Rivera et al., 2004; Lee et al., 2005; Blaesse et al., 2009). We tested whether the increased KCC2 activity induced by extra- 

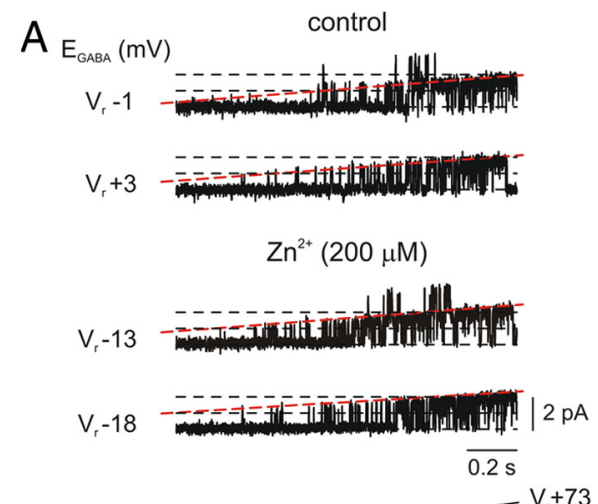

$\mathrm{V}_{\mathrm{r}}+73$
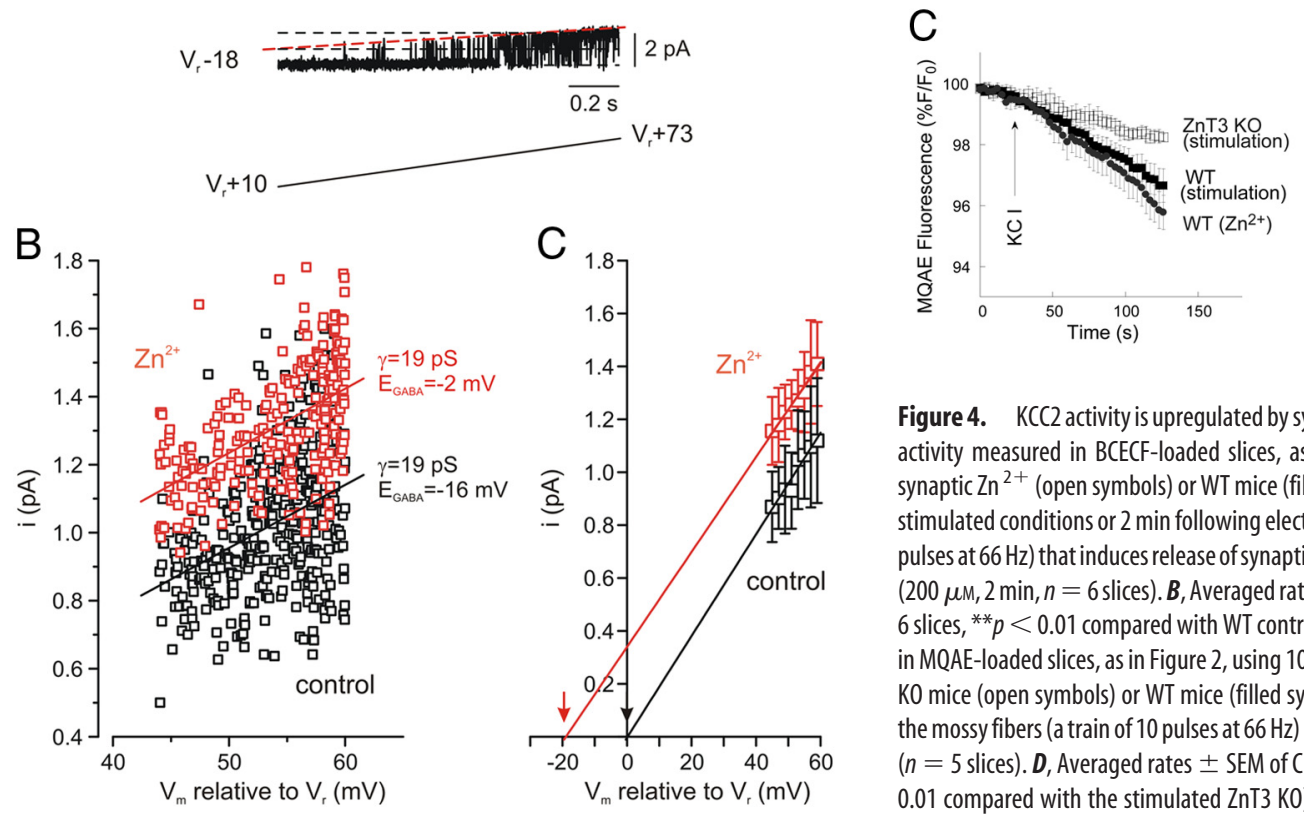

Figure 4. KCC2 activity is upregulated by synaptic $Z n^{2+}$ released from mossy fibers. $A, K C C 2$ activity measured in BCECF-loaded slices, as in Figure 1. Slices from ZnT3 KO mice lacking synaptic $\mathrm{Zn}^{2+}$ (open symbols) or WT mice (filled symbols) were monitored under control nonstimulated conditions or 2 min following electrical stimulation of the mossy fibers (a train of 10 pulses at $66 \mathrm{~Hz})$ that induces release of synaptic $\mathrm{Zn}^{2+}(n=6)$, or following application of $\mathrm{Zn}^{2+}$ (200 $\mu \mathrm{m}, 2 \mathrm{~min}, n=6$ slices). $\boldsymbol{B}$, Averaged rates of $\mathrm{NH}_{4}{ }^{+}$influx \pm SEM as monitored in A ( $n=$ 6 slices, ${ }^{* *} p<0.01$ compared with WT control). C, KCC2-dependent $\mathrm{Cl}^{-}$transport monitored in MQAE-loaded slices, as in Figure 2, using $10 \mathrm{~mm} \mathrm{KCl}$ to reverse KCC2 activity. Slices from ZnT3 KO mice (open symbols) or WT mice (filled symbols) were monitored following stimulation of the mossy fibers (a train of 10 pulses at $66 \mathrm{~Hz}$ ) or following application of $\mathrm{Zn}^{2+}(200 \mu \mathrm{m}, 2 \mathrm{~min})$ ( $n=5$ slices). $\boldsymbol{D}$, Averaged rates \pm SEM of $\mathrm{Cl}^{-}$influx as monitored in $\mathrm{C}\left(n=5\right.$ slices, ${ }^{* *} p<$ 0.01 compared with the stimulated ZnT3 KO). The rate of ion influx, using the $\mathrm{NH}_{4}{ }^{+}$or $\mathrm{Cl}^{-}$ transport, is enhanced following mossy fiber stimulation in slices from WT mice compared with $\mathrm{ZnT3} \mathrm{KO}$ mice, indicating that KCC2 activity is upregulated by the release of synaptic $\mathrm{Zn}^{2+}$.

Figure 3. Extracellular $\mathrm{Zn}^{2+}$ induces a hyperpolarizing shift in $\mathrm{GABA}_{\mathrm{A}}$ reversal potential. $\boldsymbol{A}$ In cell-attached recordings with $5 \mu \mathrm{M} G A B A$ in a patch pipette, $G_{A B A_{A}}$ channel reversal potential was measured by delivering slow depolarizing voltage ramps from 10 to $73 \mathrm{mV}$ relative to the membrane resting potential $\left(V_{r}+10\right.$ to $\left.V_{r}+73 \mathrm{mV}\right)$ every $15 \mathrm{~s}(n=4$ cells). Shown are two consecutive ramp current sweeps from a patch which contained $G_{A B A_{A}}$ channels, under control conditions (top) and the same patch 5 min after addition of $\mathrm{Zn}^{2+}(200 \mu \mathrm{m}, 2 \mathrm{~min}$ ) to the bath (bottom), with the respective extrapolated $E_{\mathrm{GABA}}$ values for each ramp to the left. Sweeps are leak-subtracted and digitized at $20 \mathrm{kHz}$ through a low-pass filter of $2 \mathrm{kHz}(-3 \mathrm{~dB})$. Dashed lines (red) are drawn through the closed and single-channel open state. $B$, Effect of $Z \mathrm{n}^{2+}$ application on $I-V$ relationships of the current through a single $\mathrm{GABA}_{\mathrm{A}}$ channel-containing patch. Amplitudes of channel opening plotted against voltage in control (vehicle treated, black) and following $\mathrm{Zn}^{2+}$ application (red), from a representative cell. The straight lines are linear fits of the data. Notice that the channel slope conductance remains unchanged (19pS), the extrapolated $E_{\mathrm{GABA}}$, however, shifted from the membrane resting potential from -2 to $-16 \mathrm{mV}$ following $\mathrm{Zn}^{2+}$ application. C, Mean unitary current amplitudes binned with a step of $2 \mathrm{mV}$ and averaged over all patches. Note that the $x$-axis intercepts of the two fitted lines (indicated by arrows) give the reversal potential values of $V_{r}-2.3 \pm 0.5 \mathrm{mV}$ in control and $V_{r}-17 \pm 2 \mathrm{mV}$ following $\mathrm{Zn}^{2+}$ application.

cellular $\mathrm{Zn}^{2+}$ altered $E_{\mathrm{GABA}}$ in cell-attached patch recordings from the somata of CA3 neurons (Chudotvorova et al., 2005; Lee et al., 2005; Tyzio et al., 2006). With $5 \mu \mathrm{M}$ GABA in the pipette solution, single or multiple $\mathrm{GABA}_{\mathrm{A}}$ channel openings were observed in all patches tested $(n=4)$, while no such openings were seen in the absence of GABA $(n=4)$, or with GABA in the presence of picrotoxin $(100 \mu \mathrm{M}, n=3)$. $E_{\mathrm{GABA}}$ values were initially extrapolated by monitoring channel opening while applying slow $(40 \mathrm{mV} / \mathrm{s})$ depolarizing voltage ramps (Fig. $3 A$ ). In control conditions, currents through the $\mathrm{GABA}_{\mathrm{A}}$ channels reversed very near the resting membrane potential $V_{\mathrm{r}}\left(E_{\mathrm{GABA}}=\right.$ $-2.3 \pm 0.5 \mathrm{mV}$ relative to $V_{\mathrm{r}}$ ), in agreement with previous observations (Tyzio et al., 2006). However, following treatment with $200 \mu \mathrm{M} \mathrm{Zn}{ }^{2+}(2 \mathrm{~min}) E_{\mathrm{GABA}}$ in the same patches shifted to more negative values ( $-17 \pm 2 \mathrm{mV}$ relative to $\left.V_{\mathrm{r}}, n=4\right)$ for the duration of the recordings ( $\geq 5$ min following $\mathrm{Zn}^{2+}$ application). The negative $\mathrm{Zn}^{2+}$-induced shift of $E_{\mathrm{GABA}}$ was also calculated by measuring individual channel amplitudes in each cell-attached patch before and after $\mathrm{Zn}^{2+}$ exposure (Fig. 3B). The same results were obtained when $E_{\mathrm{GABA}}$ values were averaged from binned amplitudes across all patches (Fig. $3 C, n=4$ ). In all, $\mathrm{Zn}^{2+}$ exposure induced a shift in $E_{\mathrm{GABA}}$ of $\sim-15 \mathrm{mV}$ without changing the channel slope conductance, as determined from linear fits to the $I-V$ curves of the single open channels. Importantly, $\mathrm{Zn}^{2+}$ did not affect the resting membrane potential measured under whole-cell recording conditions in a separate group of neurons $\left(V_{\mathrm{r}}=-79.0 \pm 5.3 \mathrm{mV}\right.$, control; $\left.-78.6 \pm 5.0 \mathrm{mV}, \mathrm{Zn}^{2+} ; n=4\right)$. Using the Stern-Volmer equation (see Materials and Methods), we estimated that $\mathrm{Zn}^{2+}$ exposure led to a $10 \pm 1 \mathrm{~mm}$ decrease in $\left[\mathrm{Cl}^{-}\right]_{\mathrm{i}}$. Alterations in the $\mathrm{Cl}^{-}$gradient of this magnitude would be expected to induce $\sim \mathrm{a}-20 \mathrm{mV}$ change in $E_{\mathrm{GABA}}$, in very close agreement to our experimental findings.

\section{Synaptically released $\mathrm{Zn}^{2+}$ upregulates KCC2 activity}

We then asked whether the synaptically released $\mathrm{Zn}^{2+}$ could also regulate KCC2 activity. Electrical stimulation of mossy fibers (a train of 10 pulses at $66 \mathrm{~Hz}$ ), previously shown to trigger $\mathrm{Zn}^{2+}$ release (Qian and Noebels, 2005) and mZnR activation (Besser et al., 2009), significantly enhanced $\mathrm{NH}_{4}{ }^{+}$influx rates in BCECFloaded hippocampal slices compared with the influx rates in nonstimulated, control, slices (Fig. 4A,B). While the mossy fiber stimulation triggers local release of synaptic- $\mathrm{Zn}^{2+}$ we observe a significant, albeit probably underestimated, metabotropic $\mathrm{Ca}^{2+}$ 
response in the postsynaptic region where the ROIs are selected (Besser et al., 2009) and in accordance, a significant change in KCC2 activity is monitored. In fact, mossy fiber stimulation enhanced KCC2 transport in CA3 neurons to a degree similar to that obtained following exogenous $\mathrm{Zn}^{2+}$ exposure (Fig. 1). To determine the role of the synaptic $\mathrm{Zn}^{2+}$ we studied KCC2 activity in slices from $\mathrm{ZnT} 3 \mathrm{KO}$ mice. These mice lack synaptic $\mathrm{Zn}^{2+}$, but otherwise exhibit little alterations in glutamatergic synaptic transmission in this hippocampal region (Lopantsev et al., 2003). Control slices from ZnT3 $\mathrm{KO}$ and wild-type mice showed similar basal KCC2 activity rates (Fig. $4 A, B$ ), suggesting that the lack of $\mathrm{ZnT} 3$ does not affect intracellular $\mathrm{Zn}^{2+}$ levels, which could affect KCC2 activity (Hershfinkel et al., 2009). In slices obtained from ZnT3 KO mice, mossy fiber stimulation had no effect on $\mathrm{NH}_{4}{ }^{+}$ influx rates. Our previous work suggests that $\mathrm{ZnR}$ activity can be triggered in slices from $\mathrm{ZnT} 3 \mathrm{KO}$ mice with exogenous $\mathrm{Zn}^{2+}$ (Besser et al., 2009). We therefore asked whether KCC2 activity could be upregulated in slices from $\mathrm{ZnT} 3 \mathrm{KO}$ mice upon addition of $\mathrm{Zn}^{2+}$. Slices from $\mathrm{ZnT} 3 \mathrm{KO}$ mice were treated with $\mathrm{Zn}^{2+}(200$ $\mu \mathrm{M}, 2 \mathrm{~min}$ ) and KCC2 activity was measured using BCECF. Application of $\mathrm{Zn}^{2+}$ did induce an increase in $\mathrm{NH}_{4}{ }^{+}$transport rate in this preparation (Fig. $4 A, B$ ), indicating that the signaling cascade linking ZnR activation to increased KCC2 activity remains intact in the absence of vesicular $\mathrm{Zn}^{2+}$. Finally, additional experiments were performed using MQAE. Stimulation of slices obtained from ZnT3 $\mathrm{KO}$ animals induced a lower $\mathrm{Cl}^{-}$influx rate compared with that of stimulated or $\mathrm{Zn}^{2+}$-treated slices from WT mice (Fig. 4C,D). Together, these results demonstrate that KCC2 activity in CA3 neurons is increased by stimulusdependent release of synaptic $\mathrm{Zn}^{2+}$ from mossy fibers.

\section{$\mathrm{Zn}^{2+}$ upregulates $\mathrm{KCC} 2$ activity via $\mathrm{ZnR}$ signaling and increase in KCC2 surface expression}

Synaptically released $\mathrm{Zn}^{2+}$ acts via a Gq-protein-coupled receptor $\mathrm{mZnR}$ to trigger intracellular $\mathrm{Ca}^{2+}$ release followed by activation of ERK1/2 (Besser et al., 2009). We tested whether activation of this pathway is linked to the upregulation of KCC2 activity following synaptic $\mathrm{Zn}^{2+}$ release. Application of either the G $\alpha$ q inhibitor YM-254890 ( $1 \mu \mathrm{M})$ or the PLC inhibitor U73122 $(1 \mu \mathrm{M})$, both of which block mZnR-mediated intracellular $\mathrm{Ca}^{2+}$ rises (Besser et al., 2009), prevented mossy fiber stimulationdependent increases in KCC2 activity (Fig. 5A,B). This suggests that $\mathrm{mZnR}$-dependent rise in intracellular $\mathrm{Ca}^{2+}$ is essential for upregulation of KCC2 activity. mZnR-dependent $\mathrm{Ca}^{2+}$ rises also trigger intracellular signaling leading to activation of mitogenactivated protein kinase (MAPK) pathways (Hershfinkel et al., 2007). Phosphorylation has been also implicated in regulation of KCC2 activity (Rinehart et al., 2009). Inhibition of ERK1/2 MAPK activation by U0126 ( $1 \mu \mathrm{M})$ completely reversed the $\mathrm{Zn}^{2+}$-dependent upregulation of KCC2 activity (Fig. $5 A, B$ ). These results indicate that increased KCC2 activity, triggered by synaptic $\mathrm{Zn}^{2+}$, is mediated by a MAPK pathway previously shown to be activated by a mZnR in neurons (Besser et al., 2009).

Rapid endocytosis followed by degradation, or recycling of KCC2 protein to the plasma membrane is an important regulatory mechanism for the activity of the cotransporter (Rivera et al., 2002, 2004; Wake et al., 2007). We therefore asked whether $\mathrm{mZnR}$ activation affects these processes by assaying KCC2 residual surface expression level using a biotinylation assay (see Materials and Methods). Following biotin labeling of surface proteins, $\mathrm{mZnR}$ activity was triggered ( $\left.200 \mu \mathrm{M} \mathrm{Zn^{2+ }}, 2 \mathrm{~min}\right)$ and slices were maintained in ACSF for $\sim 6$ min until lysed and mixed with Neutravidin. It is important to note here that the $\mathrm{Zn}^{2+}$ -
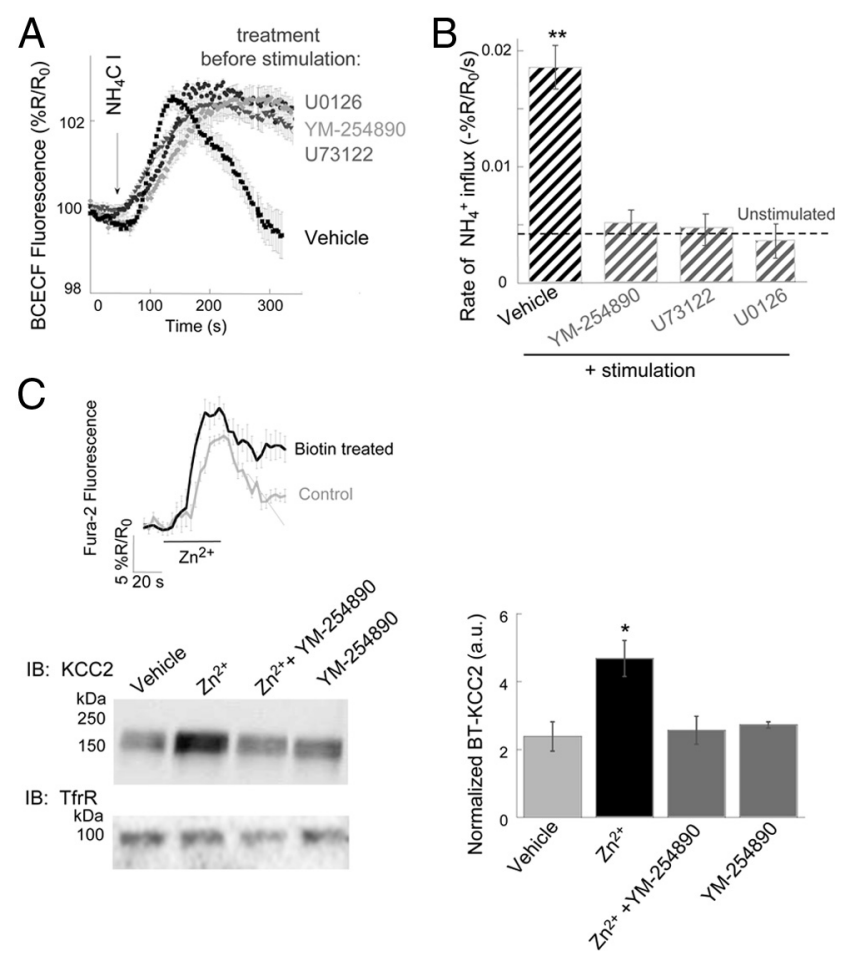

Figure 5. Upregulation of $\mathrm{KCC} 2$ activity is mediated by $\mathrm{mZnR}$ signaling pathway and enhanced KCC2 surface expression. $A, K C C 2$ activity was monitored in slices from WT mice loaded with BCECF, following stimulation of the mossy fibers in control slices (vehicle) or in slices pretreated with a $\mathrm{G} \alpha \mathrm{q}$ inhibitor (YM-254890, $1 \mu \mathrm{M}$ ), a PLC inhibitor (U73122, 1 $\mu \mathrm{M})$ or an ERK1/2 inhibitor (U0126, $1 \mu \mathrm{M}) ; n=7$ slices. B. Averaged rate of $\mathrm{NH}_{4}{ }^{+}$influx as monitored in $A$. Dashed line indicates the rate of transport in nonstimulated control slices taken from Figure $4 A$ ( $n=7$ slices, ${ }^{* *} p<0.01$ compared with vehicle control without stimulation). C, Top, Slices were biotinylated, control slices were maintained in ACSF, and loaded with the intracellular $\mathrm{Ca}^{2+}$-sensitive dye, Fura-2. Then $\mathrm{Zn}^{2+}(200 \mu \mathrm{m})$ was applied and the $\mathrm{Ca}^{2+}$ response is shown in control and biotinylated slices. Bottom, Surface expression level of $\mathrm{KCC}$, monitored using surface biotinylation followed by immunoblotting of $\mathrm{KCC} 2$ or transferrin receptor (TrfR), which is a nonrelated membrane transporter used as control. Surface expression in vehicle-control slices or in slices treated with $\mathrm{Zn}^{2+}$ in the presence or absence of YM-254890 $(1 \mu \mathrm{M})$. Densitometry analysis of $\mathrm{KCC} 2$ surface expression is shown to the right, normalized to TrfR expression ( $n=4$ slices, ${ }^{*} p<0.05$ compared with vehicle control).

dependent $\mathrm{Ca}^{2+}$ responses, monitored using Fura-2, were essentially intact following treatment of slices with the biotinylation reagent (Fig. $5 C$, inset), indicating that this procedure did not appear to compromise $\mathrm{ZnR}$ signaling. Since biotinylated surface KCC2 (BT-KCC2) can undergo rapid endocytosis, even under baseline conditions (Rivera et al., 2004; Zhao et al., 2008), control slices were maintained in ACSF for the same time period as $\mathrm{Zn}^{2+}$-treated slices. Comparison of control and $\mathrm{Zn}^{2+}$-treated slices showed that residual levels of BT-KCC2 were significantly enhanced in $\mathrm{Zn}^{2+}$-treated slices (Fig. 5C). This suggests that $\mathrm{Zn}^{2+}$ reduces the rate of endocytosis and degradation of KCC2 and/or promotes the rapid recycling of this protein to the cell membrane. Either way, there is a net increase in surface expression of KCC2 following $\mathrm{Zn}^{2+}$ stimulation, a process that can account for the observed increases in cotransporter activity observed in this study. Importantly, the effects of $\mathrm{Zn}^{2+}$ on the surface expression of KCC2 were prevented by YM-254890 ( $1 \mu \mathrm{M}$; Fig. $5 C$ ), which blocks the $\mathrm{ZnR}$-dependent intracellular $\mathrm{Ca}^{2+}$ rise (Besser et al., 2009). This strongly suggests that $\mathrm{Zn}^{2+}$-dependent overall increase in KCC2 surface expression is induced by the activation of a Gq-coupled mZnR. 


\section{GPR39 mediates ZnR signaling in CA3 neurons}

Our previous work suggested that the Gqcoupled receptor GPR39 may mediate $\mathrm{mZnR}$ activity, and demonstrated that this protein is strongly expressed in CA3 neurons (Besser et al., 2009). Here, we used hippocampal slices from GPR39 KO mice (Moechars et al., 2006) (Fig. 6A) to evaluate whether this receptor is, in fact, the mZnR. First, we determined whether synaptic $\mathrm{Zn}^{2+}$ release was similar in GPR39 KO and WT mice using the nonpermeant form of the $\mathrm{Zn}^{2+}$-sensitive dye Newport Green (Frederickson et al., 2006). Following mossy fiber stimulation (a train of 10 pulses at $66 \mathrm{~Hz}$ ), changes of Newport Green fluorescence $(2 \mu \mathrm{M}$, Fig. $6 B, C)$ in the CA3 were nearly identical in slices from WT and GPR39 KO mice, but, as expected, were absent in slices from ZnT3 KO mice (Cole et al., 1999; Carter et al., 2011). As such, the lack of GPR39 does not influence synaptic $\mathrm{Zn}^{2+}$ release.

We then evaluated mossy-fiber stimulation-dependent activation of the metabotropic pathway, leading to release of $\mathrm{Ca}^{2+}$, using slices loaded with Fura-2. While mossy fiber stimulation triggered pronounced intracellular $\mathrm{Ca}^{2+}$ responses in CA3 neurons in slices from WT mice (Besser et al., 2009), these responses were attenuated by 50\% in GPR39-defficient slices (Fig. $6 D, E$ ). The residual response is most likely induced by group I metabotropic glutamate receptor activation (Bianchi et al., 1999; Kapur et al., 2001). Moreover, any residual $\mathrm{Ca}^{2+}$ responses observed in GPR39 KO slices were unaffected by extracellular $\mathrm{Zn}^{2+}$ chelation with CaEDTA (150 $\mu \mathrm{M}$; Fig. $6 D, E)$. This chelator, however, reduced mossy fiber stimulus-evoked $\mathrm{Ca}^{2+}$ responses in WT slices to levels nearly identical to those observed in the GPR39 KO slices. These results are very similar to those previously observed in $\mathrm{ZnT} 3 \mathrm{KO}$ mice (Besser et al., 2009), and reinforce the notion that synaptically released $\mathrm{Zn}^{2+}$ via activation of a $\mathrm{mZnR}$ is responsible for a substantial component of metabotropic $\mathrm{Ca}^{2+}$ responses in CA3 neurons. Importantly, we demonstrate here that GPR39 is critical for $\mathrm{Zn}^{2+}$-dependent $\mathrm{Ca}^{2+}$ responses as no responses were observed in slices obtained from animals lacking this receptor, indicating, for the first time, that endogenous GPR39 mediates $\mathrm{mZnR}$ signaling in the hippocampus. In fact, this strongly implies that the mZnR and GPR39 are one and the same molecule.

Finally, we compared the rates of $\mathrm{NH}_{4}{ }^{+}$transport under control conditions and following either $\mathrm{Zn}^{2+}$ exposure or mossy fiber stimulation in slices from GPR39 KO mice and WT littermates. Electrical stimulation of the mossy fibers (a train of 10 pulses at $66 \mathrm{~Hz})$ or application of exogenous $\mathrm{Zn}^{2+}(200 \mu \mathrm{M}, 2$ $\mathrm{min})$ resulted in robust increase in KCC2 activity in slices obtained from WT controls (Fig. $7 A, B$ ). Strikingly however, neither
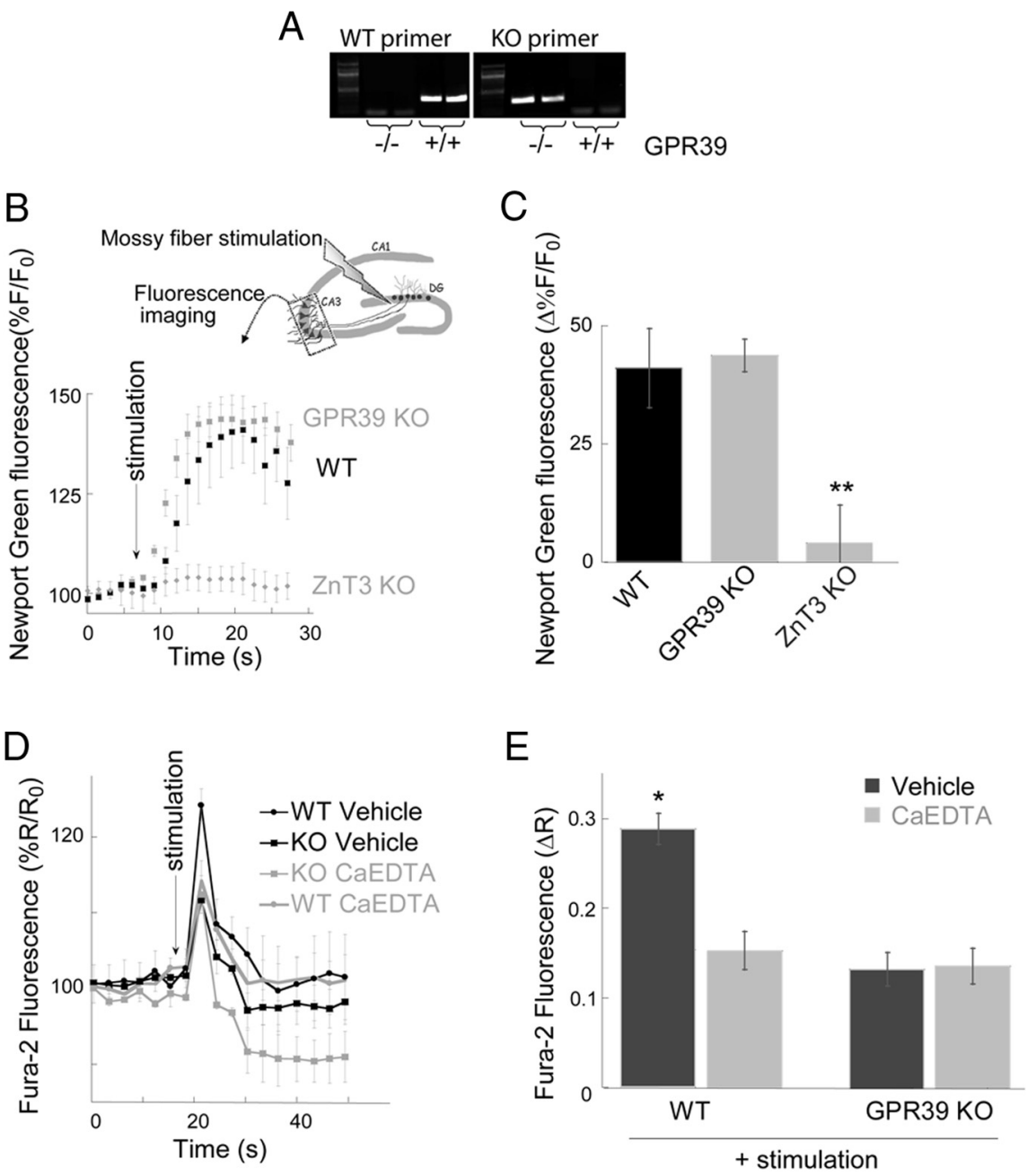

Figure 6. GPR39 mediates $\mathrm{mZnR}$-dependent $\mathrm{Ca}^{2+}$ response in CA3 hippocampal neurons. $A$, Analysis of GPR39 transcripts was determined using PCR. The WT allele gives a 311 bp and the targeted GPR39 K0 allele gives a 262 bp PCR product. This identifies CA3 region following stimulation of the mossy fibers in slices from WT mice, GPR39 K0 mice or ZnT3 K0 mice, lacking synaptic . Inset is a schematic model of the experimental setup. C, Averaged stimulation-dependent rise of Newport Green fluoresslices, ${ }^{* *} p<0.01$ compared with the GPR39 WT). D, Slices from WT or GPR39 K0 mice were loaded with Fura-2, an intracellular $\mathrm{Ca}^{2+}$-sensitive dye. Intracellular $\mathrm{Ca}^{2+}$ rise was monitored following stimulation of the mossy fibers (a train of 10 pulses at $66 \mathrm{~Hz}$, at the indicated time) in the presence of ACSF solution (vehicle) or ACSF containing the extracellular $\mathrm{Zn}^{2+}$ chelator CaEDTA (100 $\mu \mathrm{m})\left(n=7\right.$ slices). $\boldsymbol{E}$, Averaged change of $\mathrm{Ca}^{2+}$ rises as monitored in $\mathrm{D}$ ( $n=7$ slices, ${ }^{* *} p<0.01$ compared with stimulated WT in ACSF). Note that the residual $\mathrm{Ca}^{2+}$ response in the slices from GPR39 KO mice is not attenuated further by CaEDTA and is similar to the response observed in the presence of CaEDTA in slices from WT mice.

stimulus could alter KCC2 activity in slices from GPR39 KO mice (Fig. 7A-C). In agreement, a similar stimulatory effect of extracellular $\mathrm{Zn}^{2+}$ on KCC2 activity was observed in the SHSY-5Y neuronal cell line, which exhibits GPR39-mediated mZnR activity (Fig. 7D, inset) (Besser et al., 2009). Finally, siRNA-mediated silencing of GPR39 effectively abolished $\mathrm{Zn}^{2+}$-dependent $\mathrm{Ca}^{2+}$ release (Fig. 7D, inset) and the upregulation of KCC2 activity in the SHSY-5Y cells (Fig. 7D). These data also argues for the identity of GPR39 as the zinc receptor.

\section{Discussion}

GPR39, a previously orphan G-protein-coupled receptor, was first proposed to mediate obestatin signaling and regulate food intake (Zhang et al., 2005). However, the absence of GPR39 expression in the hypothalamus (Jackson et al., 2006) and the iden- 

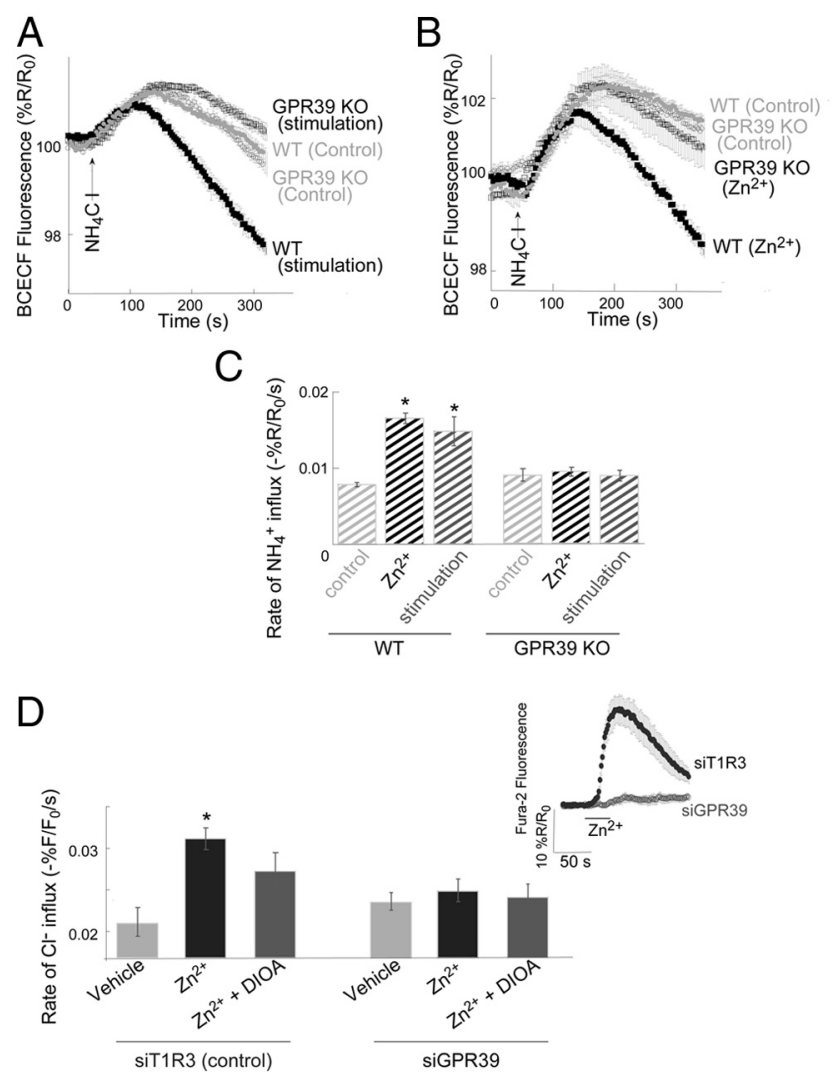

Figure 7. GPR39 mediates $\mathrm{Zn}^{2+}$-dependent upregulation of $\mathrm{KCC} 2$ activity. $A, \mathrm{KCC} 2$ activity was studied using the BCECF paradigm. $\mathrm{NH}_{4}{ }^{+}$influx rate was monitored in slices from WT (filled symbols) or GPR39 KO (open symbols) mice loaded with BCECF. BCECF fluorescence changes were monitored in slices following mossy fiber stimulation (a train of 10 pulses at 66 $\mathrm{Hz}$ ) or in control nonstimulated slices ( $n=6$ slices). $\boldsymbol{B}$, Slices from WT (filled symbols) or GPR39 KO (open symbols) mice (as in $\boldsymbol{A}$ ) were pretreated with extracellular $\mathrm{Zn}^{2+}(200 \mu \mathrm{m}, 2 \mathrm{~min}$ ) or controls ( $n=6$ slices) and $\mathrm{NH}_{4}{ }^{+}$influx rate was monitored. C, Averaged rates of $\mathrm{NH}_{4}{ }^{+}$influx as monitored in A-B ( $n=6$ slices, ${ }^{*} p<0.05$ compared with WT control). In slices from GPR39 $\mathrm{K} 0$ mice, application of exogenous $\mathrm{Zn}^{2+}$ or synaptic $\mathrm{Zn}^{2+}$ release by mossy fiber stimulation did not affect KCC2 activity, which was similar to the level of the transporter activity in control slices obtained from WT mice. D, SHSY-5Y cells were transfected with siRNA constructs for silencing GPR39 (Besser et al., 2009) or a nonrelated G-protein-coupled receptor (siT1R3, control) and subjected to the MQAE paradigm to monitor KCC2 activity. Cells were treated with or without $\mathrm{Zn}^{2+}(200 \mu \mathrm{m}, 2 \mathrm{~min})$ and $\mathrm{KCC} 2$ activity was monitored in the presence or absence of $\operatorname{DIOA}\left(n=5,{ }^{*} p<0.05\right.$ compared with vehicle siT1R3, control). $\mathrm{Zn}^{2+}$-dependent $\mathrm{Ca}^{2+}$ rise was monitored using Fura-2 (see inset) and was attenuated in the siGPR39 transfected cells.

tification of $\mathrm{Zn}^{2+}$, rather than obestatin, as its putative endogenous ligand (Yasuda et al., 2007), left this receptor without known physiological roles. The localization of GPR39 to CA3 neurons (Besser et al., 2009), as well as the results presented here using a genetic model (Moechars et al., 2006), indicate that GPR39 is responsible for endogenous $\mathrm{mZnR}$-dependent metabotropic responses in the hippocampus. We propose that a fundamental role for $\mathrm{mZnR} / \mathrm{GPR} 39$ in CA3 is to initiate signaling affecting the excitability of postsynaptic neurons following activity-dependent release of vesicular $\mathrm{Zn}^{2+}$ from mossy fiber terminals. Interestingly, synaptic $\mathrm{Zn}^{2+}$-dependent activation of ERK1/2 was recently implicated in hippocampal-dependent contextual discrimination (Sindreu et al., 2011). Our previous results suggest that $\mathrm{mZnR}$-dependent signaling induced activation of ERK1/2 in the postsynaptic cells in the hippocampus (Besser et al., 2009), hence the identification of GPR39 as the receptor mediating $\mathrm{Zn}^{2+}$-dependent ERK1/2 activation may, in future work, implicate GPR39 as a novel signaling component for memory formation.

The present study and our pervious results (Hershfinkel et al., 2009) demonstrate that synaptic and intracellular $\mathrm{Zn}^{2+}$ have opposite effects on KCC2 activity. Synaptically released, extracellular $\mathrm{Zn}^{2+}$, acting via a $\mathrm{mZnR}$, enhances KCC2 activity and surface expression, thereby inducing a hyperpolarizing shift in $\mathrm{GABA}_{\mathrm{A}}$ reversal potential. Activation of ERK1/2 by extracellular $\mathrm{Zn}^{2+}$ is essential for the upregulation of KCC2 activity, suggesting that phosphorylation of KCC2 may be required to enhance its activity. Previous studies have shown that direct phosphorylation of KCC2 regulates its activity (Strange et al., 2000; Rinehart et al., 2009; Kahle et al., 2010) and may also lead to enhanced KCC2 surface expression (Lee et al., 2007, 2010; Wake et al., 2007; Watanabe et al., 2009). In contrast to the effects of extracellular $\mathrm{Zn}^{2+}$, increases in intracellular $\mathrm{Zn}^{2+}$, triggered either by a $\mathrm{Zn}^{2+}$ ionophore or by injurious stimuli such as oxygen-glucose deprivation, inhibit KCC2 activity (Hershfinkel et al., 2009), possibly by directly interacting with the cotransporter. This leads to a depolarizing shift in the $\mathrm{GABA}_{\mathrm{A}}$ reversal potential, which may contribute to the injurious process (Buzsàki et al., 1989; Dietz et al., 2008; Papp et al., 2008). Seemingly consistent with such a mechanism, Zip-deficient mice, which lack $\mathrm{Zn}^{2+}$ influx mediating transporters, were shown to have reduced sensitivity to kainate-induced neuronal death (Qian et al., 2011). Because cytoplasmic free $\mathrm{Zn}^{2+}$ ions will interact equally well with existing or newly inserted plasma membrane KCC2, the rise in intracellular $\mathrm{Zn}^{2+}$ would be expected to induce an overall attenuation of KCC2 activity, overriding the upregulation of this transporter by extracellular $\mathrm{Zn}^{2+}$, which is, in fact what we observe.

Synaptic $\mathrm{Zn}^{2+}$ accumulation is developmentally regulated, this ion is observed in synaptic vesicles only after the first postnatal week (Frederickson et al., 1981; Nitzan et al., 2002), somewhat resembling developmental KCC2 expression ( $\mathrm{Lu}$ et al., 1999; Rivera et al., 1999; Lee et al., 2005). While in the mouse hippocampus some vesicular $\mathrm{Zn}^{2+}$ is observed at postnatal day 6 , the levels of this metal are substantially increased during the 2-3 postnatal weeks (Nitzan et al., 2002; Liguz-Lecznar et al., 2005). Thus, the results obtained in this study using the mossy fiber stimulation of mice on postnatal days 12-15 may be enhanced in adult mice. Interestingly, under pathophysiological conditions, changes in both synaptic $\mathrm{Zn}^{2+}$ levels (Doering et al., 2007; Carter et al., 2011) and KCC2 expression (Huberfeld et al., 2007; Khirug et al., 2010) are also observed. BDNF, interictal-like activity and stress induce a positive shift in $E_{\mathrm{GABA}}$ mediated by reduction of KCC2 surface expression (Rivera et al., 2002, 2004; Wake et al., 2007). Moreover, certain forms of intracellular $\mathrm{Ca}^{2+}$ signaling can also induce a depolarizing shift in $E_{\mathrm{GABA}}$ that is dependent on KCC2 activity or surface expression, including coincident presynaptic and postsynaptic activity, repetitive postsynaptic firing (Woodin et al., 2003; Fiumelli et al., 2005), and release of $\mathrm{Ca}^{2+}$ via the ryanodine receptor (Fiumelli et al., 2005). In contrast, activation of a different intracellular $\mathrm{Ca}^{2+}$ signaling pathway, triggered by group I mGluRs, induces a pronounced hyperpolarizing shift in $\mathrm{GABA}_{\mathrm{A}}$ reversal potential, which is sensitive to KCC2 inhibitors (Banke and Gegelashvili, 2008). As shown here, a neuronal $\mathrm{mZnR}$, which triggers $\mathrm{Ca}^{2+}$ release via the same pathway as group I mGluRs, similarly enhances KCC2 activity and renders the inhibitory drive for GABA more effective. We show that the metabotropic $\mathrm{Ca}^{2+}$ response and its downstream ERK1/2 activation are essential for mZnR-dependent upregulation of KCC2 activity. Furthermore, our results using the G $\alpha \mathrm{q}$ inhibitor indicate that metabotropic $\mathrm{Ca}^{2+}$ responses triggered by 
mZnR are required for enhancing KCC2 surface expression. While $\mathrm{mZnR}$ activation may regulate KCC2 endocytosis, degradation, or its recycling back to the membrane our, data clearly indicate that this results in upregulation of KCC2 activity. Importantly, we show that a brief change in extracellular $\mathrm{Zn}^{2+}$ activates metabotropic signaling that is sufficient to rapidly upregulate KCC2 activity in the hippocampus. Such robust effects on CA3 pyramidal cells signaling was previously shown to result from similar stimulation protocols in the mossy fibers, also dependent on the $\mathrm{IP}_{3}$ pathway (Scott et al., 2008). Thus, synaptically released $\mathrm{Zn}^{2+}$, acting via $\mathrm{mZnR}$ signaling, may be a significant component of the dynamic regulation of KCC2 in neurons.

As KCC2 transport activity is a major determinant of the neuronal $\mathrm{GABA}_{\mathrm{A}}$-inhibitory drive, this transporter is closely associated with seizure activity (Woo et al., 2002; Huberfeld et al., 2007). mZnR-mediated upregulation of KCC2 activity may thus partly account for the reported anticonvulsive actions of $\mathrm{Zn}^{2+}$ (Elsas et al., 2009). Indeed, the fact that synaptic $\mathrm{Zn}^{2+}$ can profoundly influence inhibitory drive is concordant with the enhanced susceptibility to kainate-triggered seizures present in $\mathrm{ZnT3}$ KO mice (Cole et al., 2000). The release of vesicular $\mathrm{Zn}^{2+}$ could serve to limit kainate-triggered epileptic activity by rendering $\mathrm{GABA}_{\mathrm{A}}$ receptor inhibitory drive more effective through $\mathrm{mZnR}$ signaling via upregulation of KCC2 activity. The enhanced kainate-triggered seizure activity observed in ZnT3 KO animals could then be explained by the lack of mZnR-mediated regulation of KCC2. If synaptic $\mathrm{Zn}^{2+}$ acts via regulation of the $\mathrm{Cl}^{-}$ gradient, the presence or absence of vesicular $\mathrm{Zn}^{2+}$ may not be critical for regulating epileptic activity when $\mathrm{GABA}_{\mathrm{A}}$ receptor function is pharmacologically restricted. Interestingly, ZnT3 KO or WT mice exhibit similar susceptibility to seizures when these are generated by $\mathrm{GABA}_{\mathrm{A}}$ receptor blockers (Cole et al., 2000). The link between synaptic release of $\mathrm{Zn}^{2+}$ and modulation of GABA function described by our work may seem inconsistent with the known, subunit-dependent direct inhibitory actions of $\mathrm{Zn}^{2+}$ on $\mathrm{GABA}_{\mathrm{A}}$ receptors (Ben-Ari and Cherubini, 1991; Smart et al., 1991, 2004). Yet, $\mathrm{Zn}^{2+}$ released from excitatory synapses may have more pronounced effects on the overall function of mature inhibitory connections by altering KCC2 activity, as evidenced by the reported anticonvulsive properties of the metal.

Zinc is selectively sequestered into a subset of glutamatecontaining synaptic vesicles by ZnT3 (Palmiter et al., 1996; Wenzel et al., 1997; Cole et al., 1999; Sindreu et al., 2003) and is released in an activity and $\mathrm{Ca}^{2+}$-dependent manner from hippocampal mossy fiber terminals (Qian and Noebels, 2005, 2006). Our previous study demonstrated that $\mathrm{Zn}^{2+}$ activates $\mathrm{mZnR}$ function in CA3 neurons and that GPR39 is localized to these cells (Besser et al., 2009). Here, we show that mZnR activity is mediated by GPR39, and is absent following GPR39 knockdown. This $\mathrm{mZnR}$ activation subsequently affects the neuronal $\mathrm{Cl}^{-}$gradient. The fact that both the endogenous transmitter, released from mossy fibers, and its exogenous application produce similar physiological effects, both of which are blocked by drugs that inhibit mZnR function, satisfies the "identity of action" and the "pharmacological identity" neurotransmitter identification criteria (Werman, 1966). Moreover, $\mathrm{Zn}^{2+}$ reuptake via specific transporters (Belloni-Olivi et al., 2009), or the previously reported rapid desensitization of $\mathrm{mZnR}$ induced by $\mathrm{Zn}^{2+}$ itself (Besser et al., 2009), may provide the mechanisms required for the inactivation of this pathway. Thus, the mZnR-dependent upregulation of KCC2 activity provides compelling physiological evidence establishing $\mathrm{Zn}^{2+}$ as a neurotransmitter in the mammalian brain. The results presented here elucidate a physiological function for GPR39, a neuronal receptor for synaptically released $\mathrm{Zn}^{2+}$. By increasing membrane expression and activity of KCC2, thereby reshaping the $\mathrm{Cl}^{-}$gradient, $\mathrm{mZnR}$ renders $\mathrm{GABA}_{\mathrm{A}}$ receptor-mediated inhibitory drive more effective.

\section{References}

Aizenman E, Stout AK, Hartnett KA, Dineley KE, McLaughlin B, Reynolds IJ (2000) Induction of neuronal apoptosis by thiol oxidation: putative role of intracellular zinc release. J Neurochem 75:1878-1888.

Amaral DG, Witter MP (1989) The three-dimensional organization of the hippocampal formation: a review of anatomical data. Neuroscience 31:571-591.

Amaral DG, Scharfman HE, Lavenex P (2007) The dentate gyrus: fundamental neuroanatomical organization (dentate gyrus for dummies). Prog Brain Res 163:3-22.

Banke TG, Gegelashvili G (2008) Tonic activation of group I mGluRs modulates inhibitory synaptic strength by regulating KCC2 activity. J Physiol 586:4925-4934.

Beierlein M, Fall CP, Rinzel J, Yuste R (2002) Thalamocortical bursts trigger recurrent activity in neocortical networks: layer 4 as a frequencydependent gate. J Neurosci 22:9885-9894.

Belloni-Olivi L, Marshall C, Laal B, Andrews GK, Bressler J (2009) Localization of zip1 and zip4 mRNA in the adult rat brain. J Neurosci Res 87:3221-3230.

Ben-Ari Y, Cherubini E (1991) Zinc and GABA in developing brain. Nature 353:220-225.

Besser L, Chorin E, Sekler I, Silverman WF, Atkin S, Russell JT, Hershfinkel M (2009) Synaptically released zinc triggers metabotropic signaling via a zinc-sensing receptor in the hippocampus. J Neurosci 29:2890-2901.

Bianchi R, Young SR, Wong RK (1999) Group I mGluR activation causes voltage-dependent and -independent $\mathrm{Ca}^{2+}$ rises in hippocampal pyramidal cells. J Neurophysiol 81:2903-2913.

Bischofberger J, Engel D, Li L, Geiger JR, Jonas P (2006) Patch-clamp recording from mossy fiber terminals in hippocampal slices. Nat Protoc 1:2075-2081.

Blaesse P, Airaksinen MS, Rivera C, Kaila K (2009) Cation-chloride cotransporters and neuronal function. Neuron 61:820-838.

Blanton MG, Lo Turco JJ, Kriegstein AR (1989) Whole cell recording from neurons in slices of reptilian and mammalian cerebral cortex. J Neurosci Methods 30:203-210.

Blasco-Ibáñez JM, Poza-Aznar J, Crespo C, Marqués-Marí AI, Gracia-Llanes FJ, Martínez-Guijarro FJ (2004) Chelation of synaptic zinc induces overexcitation in the hilar mossy cells of the rat hippocampus. Neurosci Lett 355:101-104.

Bonnet U, Wiemann M (1999) Ammonium prepulse: effects on intracellular $\mathrm{pH}$ and bioelectric activity of CA3-neurones in guinea pig hippocampal slices. Brain Res 840:16-22.

Buzsàki G, Freund TF, Bayardo F, Somogyi P (1989) Ischemia-induced changes in the electrical activity of the hippocampus. Exp Brain Res 78:268-278.

Carter RE, Aiba I, Dietz RM, Sheline CT, Shuttleworth CW (2011) Spreading depression and related events are significant sources of neuronal $\mathrm{Zn}^{2+}$ release and accumulation. J Cereb Blood Flow Metab 31:1073-1084.

Chudotvorova I, Ivanov A, Rama S, Hübner CA, Pellegrino C, Ben-Ari Y, Medina I (2005) Early expression of KCC2 in rat hippocampal cultures augments expression of functional GABA synapses. J Physiol 566:671-679.

Cole TB, Wenzel HJ, Kafer KE, Schwartzkroin PA, Palmiter RD (1999) Elimination of zinc from synaptic vesicles in the intact mouse brain by disruption of the ZnT3 gene. Proc Natl Acad Sci U S A 96:1716-1721.

Cole TB, Robbins CA, Wenzel HJ, Schwartzkroin PA, Palmiter RD (2000) Seizures and neuronal damage in mice lacking vesicular zinc. Epilepsy Res 39:153-169.

Dietz RM, Weiss JH, Shuttleworth CW (2008) $\mathrm{Zn}^{2+}$ influx is critical for some forms of spreading depression in brain slices. J Neurosci 28:8014-8024.

Doering P, Danscher G, Larsen A, Bruhn M, Søndergaard C, Stoltenberg M (2007) Changes in the vesicular zinc pattern following traumatic brain injury. Neuroscience 150:93-103.

Elsas SM, Hazany S, Gregory WL, Mody I (2009) Hippocampal zinc infusion delays the development of afterdischarges and seizures in a kindling model of epilepsy. Epilepsia 50:870-879. 
Fiumelli H, Cancedda L, Poo MM (2005) Modulation of GABAergic transmission by activity via postsynaptic $\mathrm{Ca}^{2+}$-dependent regulation of $\mathrm{KCC} 2$ function. Neuron 48:773-786.

Frederickson CJ, Howell GA, Frederickson MH (1981) Zinc dithizonate staining in the cat hippocampus: relationship to the mossy-fiber neuropil and postnatal development. Exp Neurol 73:812-823.

Frederickson CJ, Giblin LJ 3rd, Rengarajan B, Masalha R, Frederickson CJ, Zeng Y, Lopez EV, Koh JY, Chorin U, Besser L, Hershfinkel M, Li Y, Thompson RB, Krezel A (2006) Synaptic release of zinc from brain slices: factors governing release, imaging, and accurate calculation of concentration. J Neurosci Methods 154:19-29.

Fukahori M, Itoh M (1990) Effects of dietary zinc status on seizure susceptibility and hippocampal zinc content in the El (epilepsy) mouse. Brain Res 529:16-22.

Galeffi F, Sah R, Pond BB, George A, Schwartz-Bloom RD (2004) Changes in intracellular chloride after oxygen-glucose deprivation of the adult hippocampal slice: effect of diazepam. J Neurosci 24:4478-4488.

Ganesh R, Janakiraman L (2008) Serum zinc levels in children with simple febrile seizure. Clin Pediatr (Phila) 47:164-166.

Goldberg HJ, Sheehy EM (1982) Fifth day fits: an acute zinc deficiency syndrome? Arch Dis Child 57:633-635.

Haas HL, Schaerer B, Vosmansky M (1979) A simple perfusion chamber for the study of nervous tissue slices in vitro. J Neurosci Methods 1:323-325.

Hamill OP, Marty A, Neher E, Sakmann B, Sigworth FJ (1981) Improved patch-clamp techniques for high-resolution current recording from cells and cell-free membrane patches. Pflugers Arch 391:85-100.

Hershfinkel M, Moran A, Grossman N, Sekler I (2001) A zinc-sensing receptor triggers the release of intracellular $\mathrm{Ca}^{2+}$ and regulates ion transport. Proc Natl Acad Sci U S A 98:11749-11754.

Hershfinkel M, Silverman WF, Sekler I (2007) The zinc sensing receptor, a link between zinc and cell signaling. Mol Med 13:331-336.

Hershfinkel M, Kandler K, Knoch ME, Dagan-Rabin M, Aras MA, Abramovitch-Dahan C, Sekler I, Aizenman E (2009) Intracellular zinc inhibits KCC2 transporter activity. Nat Neurosci 12:725-727.

Hosie AM, Dunne EL, Harvey RJ, Smart TG (2003) Zinc-mediated inhibition of GABA(A) receptors: discrete binding sites underlie subtype specificity. Nat Neurosci 6:362-369.

Huberfeld G, Wittner L, Clemenceau S, Baulac M, Kaila K, Miles R, Rivera C (2007) Perturbed chloride homeostasis and GABAergic signaling in human temporal lobe epilepsy. J Neurosci 27:9866-9873.

Jackson VR, Nothacker HP, Civelli O (2006) GPR39 receptor expression in the mouse brain. Neuroreport 17:813-816.

Kahle KT, Rinehart J, Lifton RP (2010) Phosphoregulation of the Na-K-2Cl and $\mathrm{K}-\mathrm{Cl}$ cotransporters by the WNK kinases. Biochim Biophys Acta 1802:1150-1158.

Kan I, Ben-Zur T, Barhum Y, Levy YS, Burstein A, Charlow T, Bulvik S, Melamed E, Offen D (2007) Dopaminergic differentiation of human mesenchymal stem cells - utilization of bioassay for tyrosine hydroxylase expression. Neurosci Lett 419:28-33.

Kapur A, Yeckel M, Johnston D (2001) Hippocampal mossy fiber activity evokes $\mathrm{Ca}^{2+}$ release in CA3 pyramidal neurons via a metabotropic glutamate receptor pathway. Neuroscience 107:59-69.

Khirug S, Ahmad F, Puskarjov M, Afzalov R, Kaila K, Blaesse P (2010) A single seizure episode leads to rapid functional activation of KCC2 in the neonatal rat hippocampus. J Neurosci 30:12028-12035.

Laube B, Kuhse J, Rundström N, Kirsch J, Schmieden V, Betz H (1995) Modulation by zinc ions of native rat and recombinant human inhibitory glycine receptors. J Physiol 483:613-619.

Lee H, Chen CX, Liu YJ, Aizenman E, Kandler K (2005) KCC2 expression in immature rat cortical neurons is sufficient to switch the polarity of GABA responses. Eur J Neurosci 21:2593-2599.

Lee HH, Walker JA, Williams JR, Goodier RJ, Payne JA, Moss SJ (2007) Direct protein kinase C-dependent phosphorylation regulates the cell surface Stability and activity of the potassium chloride cotransporter KCC2. J Biol Chem 282:29777-29784.

Lee HH, Jurd R, Moss SJ (2010) Tyrosine phosphorylation regulates the membrane trafficking of the potassium chloride co-transporter KCC2. Mol Cell Neurosci 45:173-179.

Liguz-Lecznar M, Nowicka D, Czupryn A, Skangiel-Kramska J (2005) Dissociation of synaptic zinc level and zinc transporter 3 expression during postnatal development and after sensory deprivation in the barrel cortex of mice. Brain Res Bull 66:106-113.
Lopantsev V, Wenzel HJ, Cole TB, Palmiter RD, Schwartzkroin PA (2003) Lack of vesicular zinc in mossy fibers does not affect synaptic excitability of CA3 pyramidal cells in zinc transporter 3 knockout mice. Neuroscience 116:237-248.

Lu J, Karadsheh M, Delpire E (1999) Developmental regulation of the neuronal-specific isoform of $\mathrm{K}-\mathrm{Cl}$ cotransporter $\mathrm{KCC} 2$ in postnatal rat brains. J Neurobiol 39:558-568.

Madry C, Betz H, Geiger JR, Laube B (2008) Supralinear potentiation of NR1/NR3A excitatory glycine receptors by $\mathrm{Zn}^{2+}$ and NR1 antagonist. Proc Natl Acad Sci U S A 105:12563-12568.

Marandi N, Konnerth A, Garaschuk O (2002) Two-photon chloride imaging in neurons of brain slices. Pflugers Arch 445:357-365.

Moechars D, Depoortere I, Moreaux B, de Smet B, Goris I, Hoskens L, Daneels G, Kass S, Ver Donck L, Peeters T, Coulie B (2006) Altered gastrointestinal and metabolic function in the GPR39-obestatin receptorknockout mouse. Gastroenterology 131:1131-1141.

Nitzan YB, Sekler I, Hershfinkel M, Moran A, Silverman WF (2002) Postnatal regulation of ZnT-1 expression in the mouse brain. Brain Res Dev Brain Res 137:149-157.

Palmiter RD, Cole TB, Quaife CJ, Findley SD (1996) ZnT-3, a putative transporter of zinc into synaptic vesicles. Proc Natl Acad Sci U S A 93:14934-14939.

Paoletti P, Vergnano AM, Barbour B, Casado M (2009) Zinc at glutamatergic synapses. Neuroscience 158:126-136.

Papp E, Rivera C, Kaila K, Freund TF (2008) Relationship between neuronal vulnerability and potassium-chloride cotransporter 2 immunoreactivity in hippocampus following transient forebrain ischemia. Neuroscience 154:677-689.

Pond BB, Galeffi F, Ahrens R, Schwartz-Bloom RD (2004) Chloride transport inhibitors influence recovery from oxygen-glucose deprivationinduced cellular injury in adult hippocampus. Neuropharmacology 47:253-262.

Qian J, Noebels JL (2005) Visualization of transmitter release with zinc fluorescence detection at the mouse hippocampal mossy fibre synapse. J Physiol 566:747-758.

Qian J, Noebels JL (2006) Exocytosis of vesicular zinc reveals persistent depression of neurotransmitter release during metabotropic glutamate receptor long-term depression at the hippocampal CA3-CA1 synapse. J Neurosci 26:6089-6095.

Qian J, Xu K, Yoo J, Chen TT, Andrews G, Noebels JL (2011) Knockout of Zn transporters Zip-1 and Zip-3 attenuates seizure-induced CA1 neurodegeneration. J Neurosci 31:97-104.

Redman PT, Hartnett KA, Aras MA, Levitan ES, Aizenman E (2009) Regulation of apoptotic potassium currents by coordinated zinc-dependent signalling. J Physiol 587:4393-4404.

Reynolds IJ (2001) Measurement of cation movement in primary cultures using fluorescent dyes. Curr Protoc Neurosci Chapter 7:Unit7.11.

Rinehart J, Maksimova YD, Tanis JE, Stone KL, Hodson CA, Zhang J, Risinger M, Pan W, Wu D, Colangelo CM, Forbush B, Joiner CH, Gulcicek EE, Gallagher PG, Lifton RP (2009) Sites of regulated phosphorylation that control K-Cl cotransporter activity. Cell 138:525-536.

Ritucci NA, Erlichman JS, Dean JB, Putnam RW (1996) A fluorescence technique to measure intracellular $\mathrm{pH}$ of single neurons in brainstem slices. J Neurosci Methods 68:149-163.

Rivera C, Voipio J, Payne JA, Ruusuvuori E, Lahtinen H, Lamsa K, Pirvola U, Saarma M, Kaila K (1999) The K+/Cl- co-transporter KCC2 renders GABA hyperpolarizing during neuronal maturation. Nature 397:251-255.

Rivera C, Li H, Thomas-Crusells J, Lahtinen H, Viitanen T, Nanobashvili A, Kokaia Z, Airaksinen MS, Voipio J, Kaila K, Saarma M (2002) BDNFinduced TrkB activation down-regulates the $\mathrm{K}+-\mathrm{Cl}-$ cotransporter KCC2 and impairs neuronal Cl- extrusion. J Cell Biol 159:747-752.

Rivera C, Voipio J, Thomas-Crusells J, Li H, Emri Z, Sipilä S, Payne JA, Minichiello L, Saarma M, Kaila K (2004) Mechanism of activitydependent downregulation of the neuron-specific $\mathrm{K}-\mathrm{Cl}$ cotransporter KCC2. J Neurosci 24:4683-4691.

Ruusuvuori E, Li H, Huttu K, Palva JM, Smirnov S, Rivera C, Kaila K, Voipio J (2004) Carbonic anhydrase isoform VII acts as a molecular switch in the development of synchronous gamma-frequency firing of hippocampal CA1 pyramidal cells. J Neurosci 24:2699-2707.

Scott R, Lalic T, Kullmann DM, Capogna M, Rusakov DA (2008) Target-cell 
specificity of kainate autoreceptor and $\mathrm{Ca}^{2+}$-store-dependent short-term plasticity at hippocampal mossy fiber synapses. J Neurosci 28:13139-13149.

Sensi SL, Yin HZ, Weiss JH (2000) AMPA/kainate receptor-triggered $\mathrm{Zn}^{2+}$ entry into cortical neurons induces mitochondrial $\mathrm{Zn}^{2+}$ uptake and persistent mitochondrial dysfunction. Eur J Neurosci 12:3813-3818.

Sensi SL, Paoletti P, Bush AI, Sekler I (2009) Zinc in the physiology and pathology of the CNS. Nat Rev Neurosci 10:780-791.

Shin JH, Namkung W, Choi JY, Yoon JH, Lee MG (2004) Purinergic stimulation induces $\mathrm{Ca}^{2+}$-dependent activation of $\mathrm{Na}+-\mathrm{K}+-2 \mathrm{Cl}-$ cotransporter in human nasal epithelia. J Biol Chem 279:18567-18574.

Sindreu CB, Varoqui H, Erickson JD, Pérez-Clausell J (2003) Boutons containing vesicular zinc define a subpopulation of synapses with low AMPAR content in rat hippocampus. Cereb Cortex 13:823-829.

Sindreu C, Palmiter RD, Storm DR (2011) Zinc transporter ZnT-3 regulates presynaptic Erk1/2 signaling and hippocampus-dependent memory. Proc Natl Acad Sci U S A 108:3366-3370.

Smart TG, Moss SJ, Xie X, Huganir RL (1991) GABAA receptors are differentially sensitive to zinc: dependence on subunit composition. Br J Pharmacol 103:1837-1839.

Smart TG, Hosie AM, Miller PS (2004) $\mathrm{Zn}^{2+}$ ions: modulators of excitatory and inhibitory synaptic activity. Neuroscientist 10:432-442.

Strange K, Singer TD, Morrison R, Delpire E (2000) Dependence of KCC2 $\mathrm{K}-\mathrm{Cl}$ cotransporter activity on a conserved carboxy terminus tyrosine residue. Am J Physiol Cell Physiol 279:C860-C867.

Stuart GJ, Dodt HU, Sakmann B (1993) Patch-clamp recordings from the soma and dendrites of neurons in brain slices using infrared video microscopy. Pflugers Arch 423:511-518.

Takeda A, Tamano H, Nagayoshi A, Yamada K, Oku N (2005) Increase in hippocampal cell death after treatment with kainate in zinc deficiency. Neurochem Int 47:539-544.

Thomas-Crusells J, Vieira A, Saarma M, Rivera C (2003) A novel method for monitoring surface membrane trafficking on hippocampal acute slice preparation. J Neurosci Methods 125:159-166.

Titz S, Hormuzdi S, Lewen A, Monyer H, Misgeld U (2006) Intracellular acidification in neurons induced by ammonium depends on KCC2 function. Eur J Neurosci 23:454-464.

Trapp S, Lückermann M, Brooks PA, Ballanyi K (1996) Acidosis of rat dorsal vagal neurons in situ during spontaneous and evoked activity. J Physiol 496:695-710.

Tyzio R, Cossart R, Khalilov I, Minlebaev M, Hübner CA, Represa A, Ben-Ari Y, Khazipov R (2006) Maternal oxytocin triggers a transient inhibitory switch in GABA signaling in the fetal brain during delivery. Science 314:1788-1792.
Verkman AS (1990) Development and biological applications of chloridesensitive fluorescent indicators. Am J Physiol 259:C375-388.

Vogt K, Mellor J, Tong G, Nicoll R (2000) The actions of synaptically released zinc at hippocampal mossy fiber synapses. Neuron 26:187-196.

Wake H, Watanabe M, Moorhouse AJ, Kanematsu T, Horibe S, Matsukawa N, Asai K, Ojika K, Hirata M, Nabekura J (2007) Early changes in KCC2 phosphorylation in response to neuronal stress result in functional downregulation. J Neurosci 27:1642-1650.

Watanabe M, Wake H, Moorhouse AJ, Nabekura J (2009) Clustering of neuronal $\mathrm{K}+-\mathrm{Cl}-$ cotransporters in lipid rafts by tyrosine phosphorylation. J Biol Chem 284:27980-27988.

Wenzel HJ, Cole TB, Born DE, Schwartzkroin PA, Palmiter RD (1997) Ultrastructural localization of zinc transporter-3 (ZnT-3) to synaptic vesicle membranes within mossy fiber boutons in the hippocampus of mouse and monkey. Proc Natl Acad Sci U S A 94:12676-12681.

Werman R (1966) Criteria for identification of a central nervous system transmitter. Comp Biochem Physiol 18:745-766.

Woo NS, Lu J, England R, McClellan R, Dufour S, Mount DB, Deutch AY, Lovinger DM, Delpire E (2002) Hyperexcitability and epilepsy associated with disruption of the mouse neuronal-specific $\mathrm{K}-\mathrm{Cl}$ cotransporter gene. Hippocampus 12:258-268.

Woodin MA, Ganguly K, Poo MM (2003) Coincident pre-and postsynaptic activity modifies GABAergic synapses by postsynaptic changes in $\mathrm{Cl}-$ transporter activity. Neuron 39:807-820.

Yasuda S, Miyazaki T, Munechika K, Yamashita M, Ikeda Y, Kamizono A (2007) Isolation of $\mathrm{Zn}^{2+}$ as an endogenous agonist of GPR39 from fetal bovine serum. J Recept Signal Transduct Res 27:235-246.

Zhang JV, Ren PG, Avsian-Kretchmer O, Luo CW, Rauch R, Klein C, Hsueh AJ (2005) Obestatin, a peptide encoded by the ghrelin gene, opposes ghrelin's effects on food intake. Science 310:996-999.

Zhang Y, Wang H, Li J, Jimenez DA, Levitan ES, Aizenman E, Rosenberg PA (2004) Peroxynitrite-induced neuronal apoptosis is mediated by intracellular zinc release and 12-lipoxygenase activation. J Neurosci 24:10616-10627.

Zhang Y, Wang H, Li J, Dong L, Xu P, Chen W, Neve RL, Volpe JJ, Rosenberg PA (2006) Intracellular zinc release and ERK phosphorylation are required upstream of 12-lipoxygenase activation in peroxynitrite toxicity to mature rat oligodendrocytes. J Biol Chem 281:9460-9470.

Zhao B, Wong AY, Murshid A, Bowie D, Presley JF, Bedford FK (2008) Identification of a novel di-leucine motif mediating $\mathrm{K}(+) / \mathrm{Cl}(-)$ cotransporter KCC2 constitutive endocytosis. Cell Signal 20:1769-1779. 